\title{
Article \\ Hydration of Hybrid Cements at Low Temperatures: A Study on Portland Cement-Blast Furnace Slag- $\mathrm{Na}_{2} \mathrm{SO}_{4}$
}

\author{
Shiju Joseph *(D) and Özlem Cizer
}

\author{
Materials and Construction, Department Civil Engineering, KU Leuven, 3001 Brussels, Belgium; \\ ozlem.cizer@kuleuven.be \\ * Correspondence: shiju.joseph@glasgow.ac.uk
}

Citation: Joseph, S.; Cizer, Ö. Hydration of Hybrid Cements at Low Temperatures: A Study on Portland Cement-Blast Furnace Slag- $\mathrm{Na}_{2} \mathrm{SO}_{4}$. Materials 2022, 15, 1914. https:// doi.org/10.3390/ma15051914

Academic Editor: Moncef L. Nehdi

Received: 24 January 2022

Accepted: 28 February 2022

Published: 4 March 2022

Publisher's Note: MDPI stays neutral with regard to jurisdictional claims in published maps and institutional affiliations.

Copyright: (C) 2022 by the authors. Licensee MDPI, Basel, Switzerland. This article is an open access article distributed under the terms and conditions of the Creative Commons Attribution (CC BY) license (https:// creativecommons.org/licenses/by/ $4.0 /)$.

\begin{abstract}
Replacement of Portland cement with high volumes of blast furnace slag is known to negatively affect the early-age properties of concrete, particularly at low temperatures. In this study, the effectiveness of $\mathrm{Na}_{2} \mathrm{SO}_{4}$ on the mechanical properties, hydration kinetics and microstructure development of a commercial CEM III/B ( 69\% slag) is investigated at 10 and $20^{\circ} \mathrm{C} . \mathrm{Na}_{2} \mathrm{SO}_{4}$ enhances compressive strength at both 10 and $20^{\circ} \mathrm{C}$, and at both early ( 1 and 7 days) and later ages (28 and 90 days). QXRD shows an increase in the degree of alite hydration at 1 day with $\mathrm{Na}_{2} \mathrm{SO}_{4}$ addition, while the degree of clinker and slag hydration is similar for all the systems from 7 to 90 days. An increase in ettringite content is observed at all ages in the systems with $\mathrm{Na}_{2} \mathrm{SO}_{4}$. Microstructure and pore structure shows densification of hydrates and reduction in porosity on addition of $\mathrm{Na}_{2} \mathrm{SO}_{4}$.
\end{abstract}

Keywords: hydration; microstructure; activation; sulfate; phase assemblage

\section{Introduction}

Ground granulated blast furnace slag or commonly denoted as blast furnace slag or just slag, is a by-product from the iron industry, that is used to replace Portland cement (PC) to enhance the performance of concrete and gain important economic and environmental benefits [1-7]. Due to its highly amorphous Ca-Si-Al-Mg glassy phase [1,2], slag is one of the most reactive supplementary cementitious materials (SCM) used in blended cements, and commonly presents latent hydraulic behavior. Owing to its high reactivity (compared to other SCMs), high calcium content and comparable specific surface area (after grinding) in comparison to PC, standards permit very high replacement levels for slag in cement. While up to 35\% replacement of PC by slag is permitted in CEM II, the permissible replacement levels may reach 95\% in CEM III according to EN 197-1, provided it meets the required quality criteria. It is estimated that around 300-360 million tonnes of slag are being produced each year globally, and this is almost entirely used for the production of blast furnace slag cements [8]. Although this is less than $1 / 10$ th of the $\sim 4$ billion tonnes of total cement produced worldwide [9], this quantity is still large enough to be worth the investment of resources to further improve its performance in concrete.

The worst issue associated with the high replacement levels of PC with slag, or any SCM in general is poor mechanical performance at early ages, and at low curing temperatures. Berodier and Scrivener [10] reported that during the initial day of hydration, blast furnace slag does not react chemically and only provides additional surface area to enhance PC hydration by filler effect [11-13]. This translates to slower strength development at early ages with increasing slag replacement levels, even though this is largely compensated at later ages [14-16].

Curing temperature has a significant effect on the kinetics of slag reaction and strength development in slag blended cements. Although low curing temperature significantly reduces the reactivity and strength development of plain PC systems, this is even more drastic in blended cements with increasing replacement levels of slag [17-20]. Although 
this is generally the case for all SCMs upon replacement with PC, only slag is replaced at such high ratios (60-90\%). The reason for the higher impact on curing temperature for SCMs can be attributed to the higher apparent activation energies of SCMs compared to PC [21-24]. Based on the Arrhenius equation, the increase in reaction rate is higher when the activation energy is on the higher side.

As the alkalinity of the pore solution significantly affects the reactivity of SCMs, a possible route is to enhance the hydration of SCM using alkali activation. Although strong activators, such as $\mathrm{NaOH}$, can significantly boost early-age hydration, the later-age mechanical properties are largely compromised, primarily due to their negative effects on PC hydration [25-28]. The high $\mathrm{pH}$ of such activators also makes it less feasible for general purposes due to the associated health risks. These issues make $\mathrm{Na}_{2} \mathrm{SO}_{4}$ attractive as it has a high solubility $(\sim 0.98 \mathrm{M})$, near neutral $\mathrm{pH}$, and low enthalpy of solution [29]. Other additions (along with $\mathrm{Na}_{2} \mathrm{SO}_{4}$ ), such as sodium gluconate [30], calcium aluminate cements and potassium aluminate sulphates [31] are found to significantly boost the compressive strength at later ages.

Compared to fly ash blended cements, the published literature on the $\mathrm{Na}_{2} \mathrm{SO}_{4}$ activation of blast furnace slag blended cements are relatively limited. Several researchers found an increase in the early-age strength with the addition of $\mathrm{Na}_{2} \mathrm{SO}_{4}$ in slag blended cements, while the later-age strength did not significantly change, or was only marginally reduced [27,31-34]. On the other hand, some studies suggest an increase in both early- and later-age strength with the addition of $\mathrm{Na}_{2} \mathrm{SO}_{4}[35,36]$. Combination of $\mathrm{Na}_{2} \mathrm{SO}_{4}$ with other additives such as alum [31], calcined gypsum [32] and sodium gluconate [30] was also found to further improve the mechanical properties. Previous studies have investigated the use of $\mathrm{Na}_{2} \mathrm{SO}_{4}$ to activate the slag in an alkali activated system without PC addition, and this was found to have very low performance at ambient temperatures, particularly at early ages $[37,38]$.

Nevertheless, in hybrid cements with PC, slag and $\mathrm{Na}_{2} \mathrm{SO}_{4}$, previous studies were carried out only at ambient temperatures, and the effect at low curing temperature is not known yet. In this study the effect of $\mathrm{Na}_{2} \mathrm{SO}_{4}$ activation on hydration of commercial CEM III/B $42.5 \mathrm{~N}$ is investigated at 10 and $20^{\circ} \mathrm{C}$. The objective of this study is to investigate whether we can compensate the slow reaction rate of blended cements at lower temperature with $\mathrm{Na}_{2} \mathrm{SO}_{4}$. The compressive strength development of mortar, kinetics of clinker and slag hydration, hydrate phase assemblage and microstructural development are investigated to unveil the effect of $\mathrm{Na}_{2} \mathrm{SO}_{4}$ activation on low temperature hydration reactions.

\section{Materials and Methods}

\subsection{Materials}

A commercial blast furnace slag cement, CEM III/B $42.5 \mathrm{~N}$, and a technical grade $\mathrm{Na}_{2} \mathrm{SO}_{4}$ were used in this study. The particle size distribution of the cement was characterized using laser diffraction after dispersion in isopropanol prior to measurement. Particle fineness was also characterized using the standard Blaine technique. The oxide composition of the cement was determined using a wavelength-dispersive X-ray fluorescence (XRF) spectrometer. The mineralogical composition was determined using quantitative $X$-ray diffraction. The amount of slag present in cement was further verified using the selective dissolution technique.

\subsection{Sample Preparation}

The experimental study was performed on paste and mortar specimens. The hydration, phase assemblage and microstructure were characterized at paste scale and the strength development was monitored on mortar scale (Table 1). All samples were prepared in a temperature-controlled room at $20^{\circ} \mathrm{C}$. $\mathrm{Na}_{2} \mathrm{SO}_{4}$ solution of strength $0.75 \mathrm{M}$ was used based on a previous study on fly ash [39]. The water to cement ratio $(w / c)$ was kept constant at 0.5 , which resulted in a higher solution to cement ratio (S/c) of $\sim 0.55$ for mixes with $\mathrm{Na}_{2} \mathrm{SO}_{4}$ 
solution. In this definition, cement includes all the binder mass including the Portland cement and blast furnace slag, and $\mathrm{Na}_{2} \mathrm{SO}_{4}$ is considered to be the part of the solution.

Table 1. Mortar mix compositions and flow values as determined with flow table test.

\begin{tabular}{cccccccc}
\hline MIX ID & $\begin{array}{c}\text { CEM III } \\
(\mathbf{g})\end{array}$ & Sand (g) & $\begin{array}{c}\text { Solution } \\
(\mathbf{g})\end{array}$ & {$\left[\mathbf{N a}_{\mathbf{2}} \mathbf{S O}_{\mathbf{4}}\right]$} & $\begin{array}{c}\text { w/c } \\
\text { Ratio }\end{array}$ & S/c Ratio & $\begin{array}{c}\text { Mortar } \\
\text { Flow } \\
(\mathbf{m m})\end{array}$ \\
\hline III & 450 & 1350 & 225 & - & 0.5 & 0.5 & $130 \pm 2$ \\
NS & 450 & 1350 & 249 & $0.75 \mathrm{M}$ & 0.5 & 0.55 & $146 \pm 3$ \\
\hline
\end{tabular}

Pastes were prepared by means of a vertical high shear mixer at $1000 \mathrm{rpm}$ for $2 \mathrm{~min}$. They were then sealed in plastic vials and cured at $10{ }^{\circ} \mathrm{C}$ and $20^{\circ} \mathrm{C}$ up to 90 days. Mortar samples were prepared following EN 196-1 using the norm sand in a Hobart mixer, and then cast into $40 \times 40 \times 160 \mathrm{~cm}$ moulds. The mortar prisms were sealed using plastic film to prevent evaporation and cured at $10^{\circ} \mathrm{C}$ and $20^{\circ} \mathrm{C}$ up to 90 days. The compressive strength development was monitored by testing the mortar bars at 1, 7, 28 and 90 days in accordance with EN 196-1 at a loading rate of $2 \mathrm{~mm} / \mathrm{min}$.

\subsection{Isothermal Calorimetry}

Heat release from $45 \mathrm{~min}$ after mixing (which also takes into account the time required for stabilization of signal in calorimeter after placing) until 7 days was measured using a TAMair 8 channel isothermal calorimeter at 10 and $20^{\circ} \mathrm{C}$. During measurements at $10^{\circ} \mathrm{C}$, the calorimeter was kept in a climate-controlled room at $10^{\circ} \mathrm{C}$ and $<60 \% \mathrm{RH}$ to avoid condensation. Around 7-8 g paste was transferred into an ampoule before placing in the calorimeter. The reference cell was filled with an ampoule filled with water having approximately equal thermal mass of samples.

\subsection{Hydration Stoppage}

Hydration of the pastes was arrested after 1, 7, 28 and 90 days of sealed curing using a freeze drier for $2 \mathrm{~h}$ at 0.025 mbar pressure after crushing them with a mortar and pestle. For MIP and electron microscopy, hydration was stopped using solvent exchange method. Samples were cut into a disc of $\sim 3-5 \mathrm{~mm}$ and immersed in isopropanol for 7 days. The solution was replaced with new isopropanol after 1 and 3 days. Afterwards, the samples were dried in a vacuum desiccator.

\subsection{TGA}

Thermogravimetric analysis (TGA) was used to quantify the total bound water content by measuring the mass loss from room temperature up to $600^{\circ} \mathrm{C}$. TGA was carried out on NETZSCH STA $409 \mathrm{PC}$, at $10^{\circ} \mathrm{C} / \mathrm{min}$ heating rate under nitrogen flow. Typically, around $20-40 \mathrm{mg}$ of the sample was used for each measurement. The portlandite content was quantified using the tangent method [40] and is reported as $\mathrm{g} / 100 \mathrm{~g}$ anhydrous cement [41]

\subsection{XRD Measurement}

$X$-ray diffraction (XRD) was carried out on hydration-arrested pastes ground to powder using a Bruker D2 phaser diffractometer with $\mathrm{Cu} \mathrm{K} \alpha$ radiation $(\lambda=1.54 \AA$ ). The samples were scanned over the range of $5-55^{\circ} 2 \theta$. Anhydrous cement was characterized using the internal standard method, mixing $20 \%$ of zincite. Additional measurements without internal standard were also conducted to aid quantification of the degree of hydration. For the quantitative analysis of the pastes, corundum was used as an external standard. Step size of $0.02^{\circ} 2 \theta$ and $0.3 \mathrm{~s} /$ step was employed. After 90 days of hydration, additional XRD measurement was performed on a freshly cut disc to further compare the effect of hydration stoppage on phase assemblage. The fresh disc of 3-5 $\mathrm{mm}$ thickness was cut from a cylinder and was gently polished with a sandpaper to flatten the surface. A slower XRD scan of $0.6 \mathrm{~s} / \mathrm{step}$ was conducted to gain higher resolution of the signal. 


\subsection{Rietveld-PONKCS Analysis}

The quantification of the phase composition was determined using the Rietveld method in Topas (Academic) software. Chebyshev polynomial with three background (bkg) parameters along with an $1 / \mathrm{X}$ term was used as the background function. The number of bkg parameters were limited to ensure that the amorphous humps from slag and C-S-H were not overfitted. Further, a fundamental parameter approach [42] was used and corrections for specimen displacement were conducted, while $5-8^{\circ} 2 \theta$ scan was omitted. For the known crystal structures, lattice parameters and crystallite size were refined while atomic parameters were not refined, as per the recommendation of [43]. Lattice parameters were not allowed to deviate more than $1 \%$ from the literature values. Corrections for preferred orientation were conducted for alite $\mathrm{M} 3$, gypsum, anhydrite and portlandite.

To quantify the degree of hydration of the amorphous slag in cement paste, the "partial or not known crystal structure" method, PONKCS, was used [44]. C-S-H structure developed by Snellings [45] for hydrated white cement was used without any further refinement. For modeling the diffraction profile of an amorphous hump of slag, a set of pseudo Voigt peaks was used and was fitted on the anhydrous slag-cement. This was based on the assumption that all the contributions of signals from non-crystalline phases were from the slag. For capturing the profile of slag, two broad peaks at d value of 2.893 and 1.926 were used. The quantification of all phases were carried out using the external standard method [46]. The scale factor of the slag phase was compared with the scale factor of the anhydrous cement, considering the mass attenuation coefficients (MAC) and the Gfactor determined from the external standard [46]. The MAC of the samples was calculated based on the oxide composition of cement determined from X-ray florescence (XRF), and bound water content determined from TGA. The expected error for the crystalline phases is $0.5 \mathrm{wt} \%$ and for the degree of hydration of amorphous slag is around $7 \%$.

\subsection{Electron Microscopy}

Samples after hydration stoppage were embedded in resin under vacuum for $24 \mathrm{~h}$. These were progressively polished with P1200 through to P4000 SiC papers with the aid of ethanol and using $3 \mu \mathrm{m}$ and $1 \mu \mathrm{m}$ diamond spray (oil-based). Electron microscopy study was carried out on FEI XL 30 FEG with EDAX energy dispersive spectrometry (EDX) detector. The accelerating voltage was $15 \mathrm{kV}$ and working distance was around $10 \mathrm{~mm}$ with field emission gun (FEG) as electron source. Images were captured on backscattered electron (BSE) mode and EDX point analysis ( $\sim 50$ measurements per sample) was done on both anhydrous grains and hydration products.

\subsection{MIP}

Mercury intrusion porosimetry (MIP) was carried out on paste samples after solvent exchange using Micromeritics AutoPORE IV 9500. The pressure was progressively increased to 30,000 psia ( $207 \mathrm{MPa}$ ). The contact angle of mercury was assumed to be $130^{\circ}$ and the surface tension to be $0.485 \mathrm{~N} / \mathrm{m}$.

\subsection{Selective Dissolution}

Selective dissolution was carried out to evaluate the slag content following the recommendation of RILEM TC 238-SCM [47], using triethanolamine (TEA), EDTA and diethylamine (DEA). A mixture of $250 \mathrm{~mL}$ TEA, $500 \mathrm{~mL}$ distilled water, $93 \mathrm{~g}$ EDTA and $173 \mathrm{~mL}$ DEA was prepared and brought to $1000 \mathrm{~mL}$ by adding distilled water. Then $50 \mathrm{~mL}$ of this solution was diluted to $800 \mathrm{~mL}$ with distilled water. Then $0.5 \mathrm{~g}$ of cement was added and stirred for $2 \mathrm{~h}$. Then it was filtered, and the residue was washed 5 times with $10 \mathrm{~mL}$ of distilled water. The residue was weighed after drying at $105^{\circ} \mathrm{C}$ for $1 \mathrm{~h}$. The results from selective dissolution of hydrated cements were discarded as XRD measurement on the selective dissolution residue showed signals of C-(A)-S-H. 


\section{Results}

\subsection{Characterisation of Cement}

Chemical composition, mineral phases and physical properties of CEM III/B $42.5 \mathrm{~N}$ are presented in Table 2 . Alite is the major phase in clinker, with $18 \%$ out of $24.3 \%$ crystalline clinker phases. The amorphous content in the cement was quantified to be $69.1 \%$, which can be assumed to have originated from the slag, as commercially produced unhydrated Portland clinker rarely contains amorphous fraction [48]. This content was also validated by the percentage of residue after selective dissolution, which was $69.4 \%$. The XRD diffractograms before and after selective dissolution are shown in Figure 1. The residue after selective dissolution was devoid of any crystal peaks. A total percentage of 3.1\% $\mathrm{CaSO}_{4}$ is present as bassanite and anhydrite, while peaks of gypsum are not observed.

Table 2. Chemical composition determined from XRF, mineralogical composition from XRD and physical properties of the cement used.

\begin{tabular}{cccccc}
\hline \multicolumn{2}{c}{ Chemical Composition } & \multicolumn{2}{c}{ Mineralogical Composition } & \multicolumn{2}{c}{ Physical Properties } \\
\hline $\mathrm{CaO}$ & 48.5 & $\mathrm{C}_{3} \mathrm{~S}$ & 18.0 & Blaine & $5024 \mathrm{~cm}^{2} / \mathrm{g}$ \\
$\mathrm{SiO}_{2}$ & 29.4 & $\mathrm{C}_{2} \mathrm{~S}$ & 2.3 & Specific & $2.99 \mathrm{~g} / \mathrm{cm}^{3}$ \\
$\mathrm{Al}_{2} \mathrm{O}_{3}$ & 8.4 & $\mathrm{C}_{3} \mathrm{~A}$ & 2.0 & gravity & \\
$\mathrm{MgO}$ & 5.4 & $\mathrm{C}_{4} \mathrm{AF}$ & 2.0 & Selective & \\
$\mathrm{SO}_{3}$ & 5.2 & Bassanite & 1.2 & dissolution & $69.4 \%$ \\
$\mathrm{Fe}_{2} \mathrm{O}_{3}$ & 1.0 & Anhydrite & 1.9 & residue & \\
$\mathrm{K}_{2} \mathrm{O}$ & 0.6 & Quartz & 0.3 & Particle size \\
$\mathrm{TiO}_{2}$ & 0.6 & Calcite & 1.0 & $\mathrm{~d} 10(\mu \mathrm{m})$ & 1.4 \\
$\mathrm{Na}_{2} \mathrm{O}$ & 0.3 & Arcanite & 1.2 & $\mathrm{~d} 50(\mu \mathrm{m})$ & 8.8 \\
$\mathrm{MnO}$ & 0.2 & Syngenite & 0.9 & $\mathrm{~d} 90(\mu \mathrm{m})$ & 21.0 \\
$\mathrm{P}_{2} \mathrm{O}_{5}$ & 0.1 & Amorphous & 69.1 & & \\
\hline
\end{tabular}

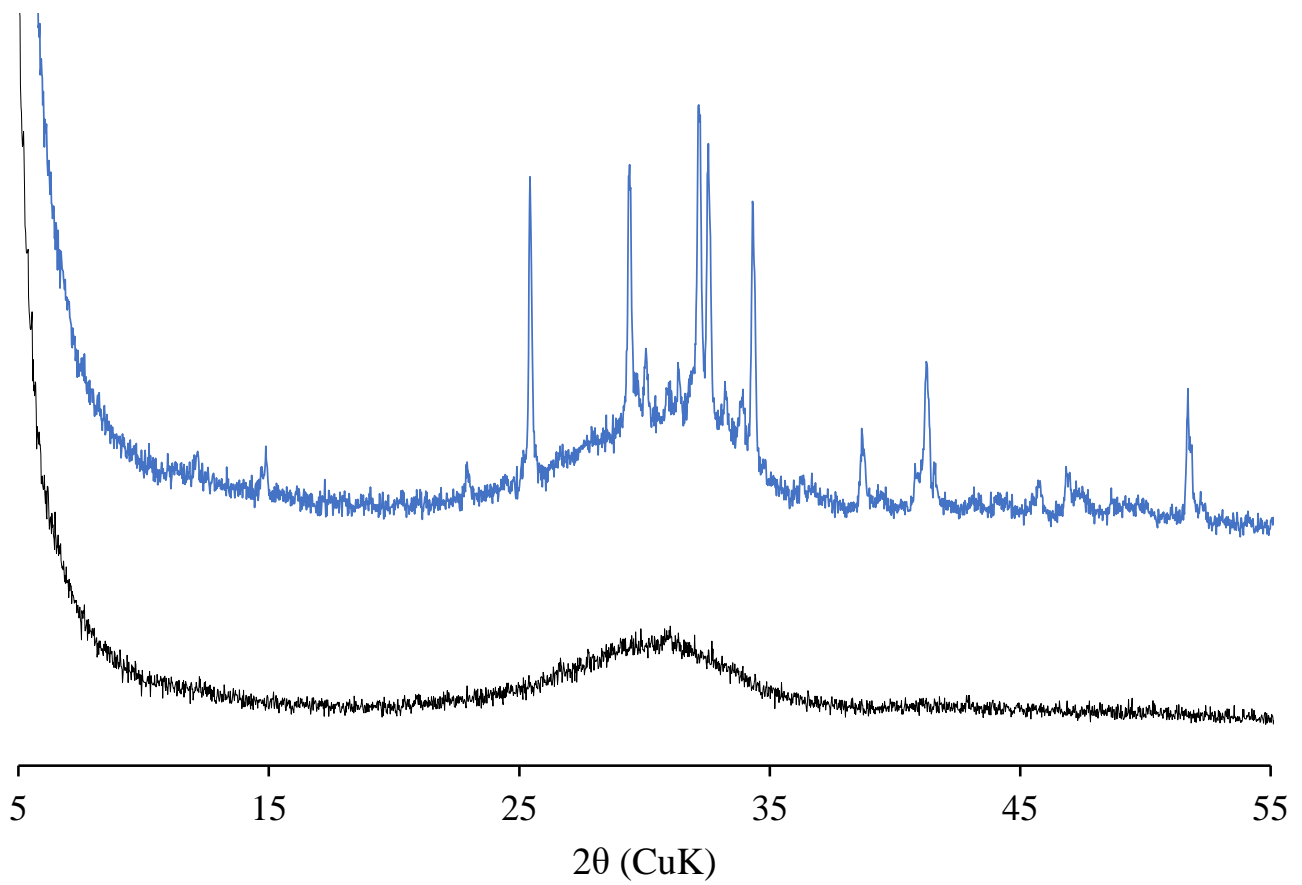

Figure 1. XRD diffractograms of CEM III before (blue) and after (black) selective dissolution. The sharp peaks correspond to the anhydrous clinker phases in the cement and the broad peak correspond to the amorphous glassy phase of slag.

Furthermore, the oxide composition and elemental ratios of the slag as determined by SEM-EDX analysis are shown in Table 3. These points were selected from hydrated pastes, and EDX point analysis was performed on the anhydrous grains. Those points were 
confirmed to be slag particles, based on the grey level intensity, the morphology and the presence of magnesium content. The measured composition seems to be very similar to typical slag compositions available in western Europe [1,2,49].

Table 3. Elemental ratios and oxide composition of anhydrous slag from SEM-EDX analysis.

\begin{tabular}{ccccccc}
\hline \multicolumn{3}{c}{ Elemental Ratios (wt \%) } & \multicolumn{4}{c}{ Oxide Composition (wt\%) } \\
\hline $\mathbf{S i} / \mathbf{C a}$ & $\mathbf{A l} / \mathbf{S i}$ & $\mathbf{M g} / \mathbf{S i}$ & $\mathbf{C a O}$ & $\mathbf{S i O}_{2}$ & $\mathbf{A l}_{\mathbf{2}} \mathbf{O}_{3}$ & $\mathbf{M g O}$ \\
$0.52 \pm 0.07$ & $0.35 \pm 0.03$ & $0.26 \pm 0.04$ & $43.3 \pm 3.5$ & $34.5 \pm 3.7$ & $10.5 \pm 1.0$ & $6.6 \pm 1.3$ \\
\hline
\end{tabular}

\subsection{Compressive Strength}

Mortar samples with CEM III/B only are denoted by III, and those with $\mathrm{Na}_{2} \mathrm{SO}_{4}$ added are denoted by NS. Additional denoting with 10 and 20 indicates the temperature of curing in ${ }^{\circ} \mathrm{C}$. The flow table value increases by around $12 \%$ with the addition of $\mathrm{Na}_{2} \mathrm{SO}_{4}$ (Table 1). This is in agreement with the previous study [39]. The effect of $\mathrm{Na}_{2} \mathrm{SO}_{4}$ solution in increasing mortar flow implies that similar flow values can be achieved by reducing the $w / c$ ratio.

Figure 2 shows that at both temperatures, all mortar mixes developed compressive strength up to 90 days. The addition of $\mathrm{Na}_{2} \mathrm{SO}_{4}$ in NS mortar mixes boosted the compressive strength at all ages and at both 10 and $20{ }^{\circ} \mathrm{C}$ when compared with III mixes. The NS mortars at 7 days yielded an increase of $10 \%$ and $20 \%$ at $10{ }^{\circ} \mathrm{C}$ and $20{ }^{\circ} \mathrm{C}$ respectively. Similarly, improvements of $37 \%$ and $10 \%$ strength were recorded at 28 and 90 days respectively for $10{ }^{\circ} \mathrm{C}$, while at $20^{\circ} \mathrm{C}$, this increment was presented around $16 \%$ and $10 \%$ respectively.

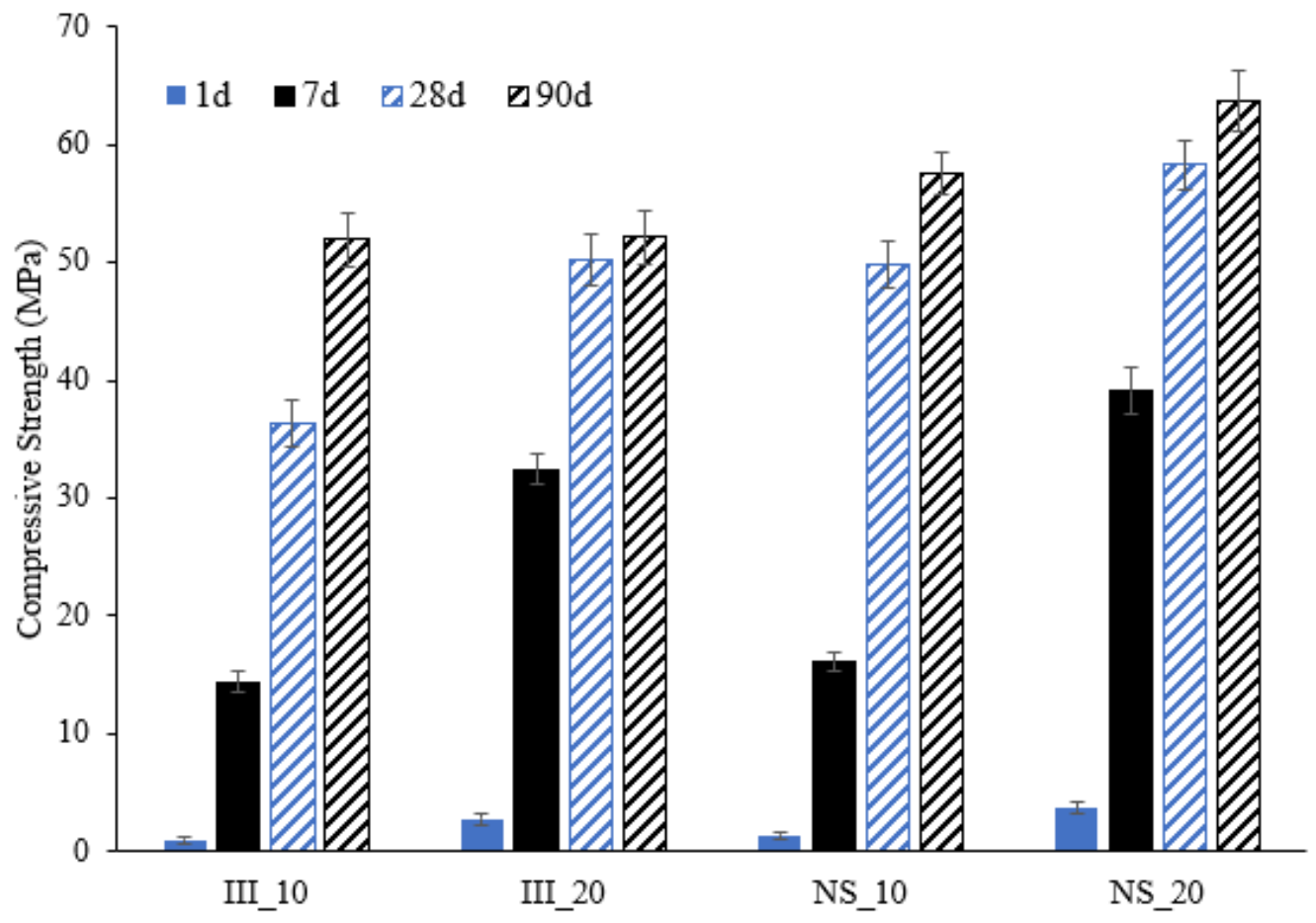

Figure 2. Compressive strength development of the mortars from 1 day until 90 days cured at 10 and $20{ }^{\circ} \mathrm{C}$. Notation: III-mixes with water and NS-mixes with $\mathrm{Na}_{2} \mathrm{SO}_{4}$ solution. 10 \& 20 represent the respective curing temperatures used.

\subsection{Hydration Kinetics}

The rate and cumulative heat of hydration of the studied mixes are shown in Figure 3a,b respectively. Two distinct peaks are clearly captured in the hydration rate curves of all the mixes. The intensity of the first peak increases with both an increase in temperature and the addition of $\mathrm{Na}_{2} \mathrm{SO}_{4}$. This indicates a higher degree of reaction of alite at early 
ages. This is further confirmed with the quantitative XRD analysis (Table 4), as the degree of hydration of alite after 1 day of hydration was significantly enhanced both with the addition of $\mathrm{Na}_{2} \mathrm{SO}_{4}[50]$ and the increase in the curing temperature.
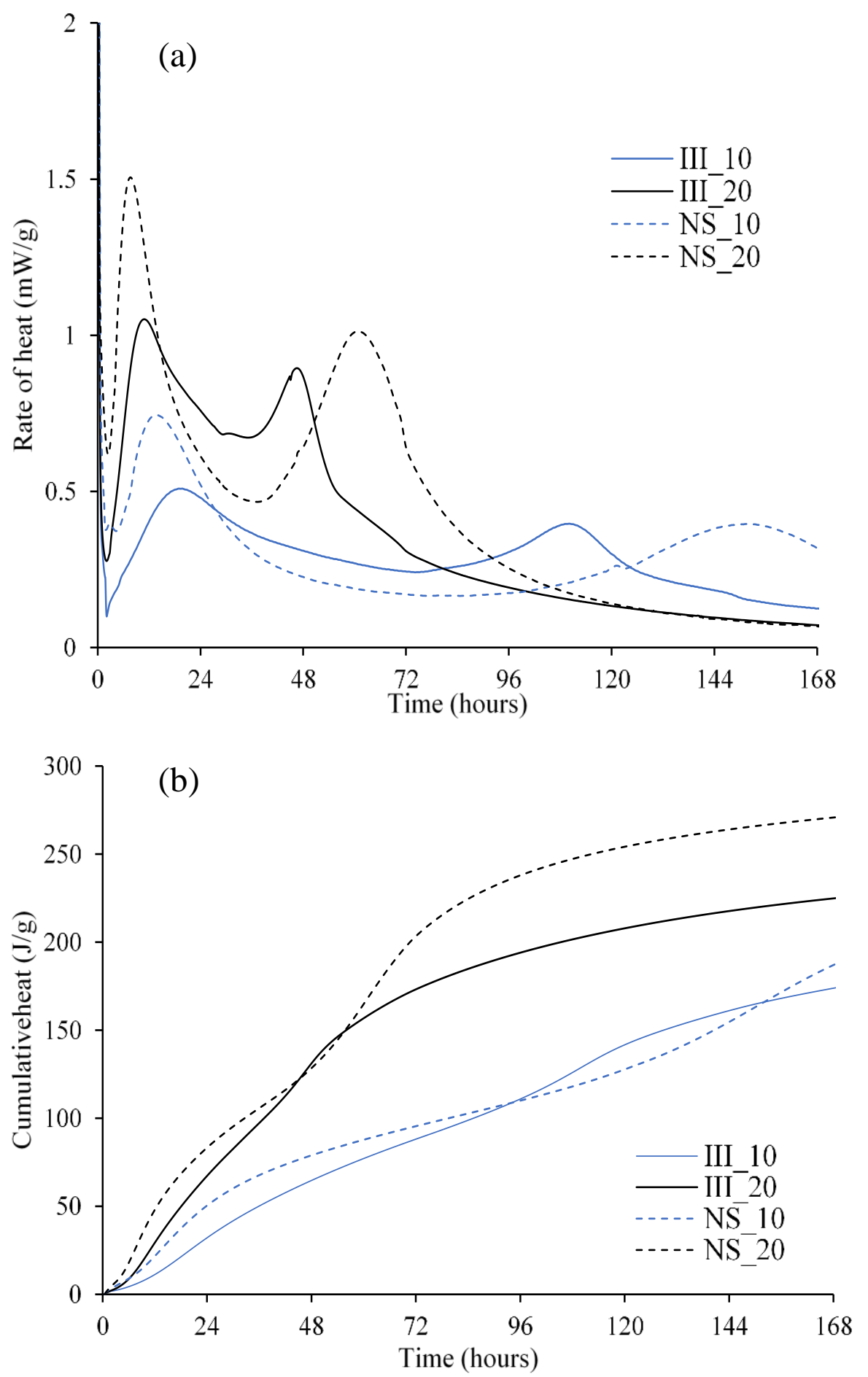

Figure 3. Rate of heat release (a) and cumulative heat (b) measured from isothermal calorimeter normalized to per gram of cement. 
Table 4. Degree of hydration (\%) and absolute weight (g/100 g anhydrous) in brackets of different clinker phases determined from XRD/Rietveld.

\begin{tabular}{cccccc}
\hline & Age (Days) & $\mathbf{C}_{3} \mathbf{S}$ & $\mathbf{C}_{2} \mathbf{S}$ & $\mathbf{C}_{3} \mathbf{A}$ & $\mathbf{C}_{4} \mathbf{A F}$ \\
\hline CEM III/B & 0 & $0(18.0)$ & $0(2.3)$ & $0(2.0)$ & $0(2.0)$ \\
$42.5 \mathrm{~N}$ & 1 & $37.4(11.3)$ & $18.4(1.9)$ & $10.6(1.8)$ & $-7.7(2.2)$ \\
& 7 & $92.5(1.3)$ & $-11.9(2.6)$ & $75.0(0.5)$ & $19.3(1.6)$ \\
III_10 & 28 & $93.8(1.1)$ & $4.9(2.2)$ & $100(0)$ & $17.1(1.7)$ \\
& 90 & $96.3(0.7)$ & $28.4(1.6)$ & $100(0)$ & $62.7(0.7)$ \\
& 1 & $70.3(5.3)$ & $0.6(2.3)$ & $17.0(1.7)$ & $38.6(1.2)$ \\
III_20 & 7 & $94.7(1.0)$ & $-14.7(2.6)$ & $94.4(0.1)$ & $40.4(1.2)$ \\
& 28 & $93.3(1.2)$ & $-13.3(2.6)$ & $100(0)$ & $51.0(1.0)$ \\
& 90 & $98.0(0.7)$ & $35.7(1.5)$ & $100(0)$ & $71.6(0.6)$ \\
NS_10 & 1 & $58.7(7.4)$ & $-13.9(2.6)$ & $30.2(1.4)$ & $6.9(1.9)$ \\
& 7 & $95.5(0.8)$ & $-19.0(2.7)$ & $78.5(0.4)$ & $17.6(1.6)$ \\
& 28 & $96.8(0.6)$ & $-2.0(2.3)$ & $65.6(0.7)$ & $27.5(1.5)$ \\
& 90 & $97.8(0.4)$ & $29.8(1.6)$ & $80.2(0.4)$ & $49.8(1.0)$ \\
NS_20 & 1 & $83.0(3.1)$ & $-4.4(2.4)$ & $53.1(0.9)$ & $35.1(1.3)$ \\
& 7 & $95.1(0.9)$ & $2.5(2.2)$ & $87.6(0.2)$ & $45.0(1.1)$ \\
& 28 & $95.2(0.9)$ & $4.6(2.2)$ & $76.1(0.5)$ & $33.6(1.3)$ \\
& 90 & $96.3(0.7)$ & $42.8(1.3)$ & $100(0)$ & $63.9(0.7)$ \\
\hline
\end{tabular}

The second peak of hydration in the reference mix (without $\mathrm{Na}_{2} \mathrm{SO}_{4}$ ) appears much earlier and sharper at $20^{\circ} \mathrm{C}$ (III_20) when compared to that at $10^{\circ} \mathrm{C}$ (III_10). This peak overlaps with the deceleration period of alite hydration and a narrower peak is seen at $20{ }^{\circ} \mathrm{C}$ compared to $10^{\circ} \mathrm{C}$. On the other hand, when $\mathrm{Na}_{2} \mathrm{SO}_{4}$ is added, this second hydration peak is delayed at both temperatures. At 7 days, the second peak is still in progress in the case of the mix with $\mathrm{Na}_{2} \mathrm{SO}_{4}$ cured at $10{ }^{\circ} \mathrm{C}$ (NS_10), while all other mixes have already past the second peak. This can explain considerably higher improvement in strength for NS_10 after 7 days (around 8-10 days) compared to others as the rate of hydration was higher during this period.

The strength trends at early ages $(1 \mathrm{~d}$ and $7 \mathrm{~d})$ resurface in the trends related to cumulative heat release (Figure $3 b)$. Total heat release was most affected by the increase in temperature. Low heat release at $1 \mathrm{~d}$ was due to rather lower alite content $(\sim 18 \%)$ compared to Portland cement (50-70\%) which resulted in a low compressive strength at $1 \mathrm{~d}$. At $20^{\circ} \mathrm{C}$, NS_20 releases higher heat consistently except for a short duration around 2 days, which overlaps with the second hydration peak. Beyond that, it releases significantly higher heat. At $10{ }^{\circ} \mathrm{C}$, NS_10 yields lower heat release between 4 and 6 days, again corresponding to the peaks of hydration. This would further translate into lower strength in this period.

Figure 4 shows the degree of hydration of clinker and Table 4 reports the degree of hydration of the individual clinker phases along with the unhydrated mass per $100 \mathrm{~g}$ of anhydrous cement determined with XRD/Rietveld analysis. Negative values appear in the table due to a combined effect of the error expected from the XRD quantification, the low contents of the phases and low degree of hydration. The degree of hydration of clinker $\left(\mathrm{DoH}_{\text {clinker }}\right)$ was calculated from the degree of hydration of the individual phases taking into account the initial mass percentage. When the measured degree of hydration of a particular phase was negative, this was assumed to be zero in the calculation of the degree of clinker hydration.

After 1 day of hydration, there were considerable variations in the $\mathrm{DoH}_{\text {clinker }}$ of the studied systems. The $\mathrm{DoH}_{\text {clinker }}$ was clearly enhanced both by temperature and $\mathrm{Na}_{2} \mathrm{SO}_{4}$ addition. At 7 days, a similar trend was visible, but the variations between the systems are much lower than that at 1 day. At 28 days, $\mathrm{DoH}_{\text {clinker }}$ was similar for all the systems, and at 90 days, the presence of $\mathrm{Na}_{2} \mathrm{SO}_{4}$ had a slightly negative effect. This trend was not similar to what was observed in the mortar strength at 28 and 90 days. This indicates that 
the contribution of clinker hydration to strength development was high at early ages, and at later ages, other factors are also at play.

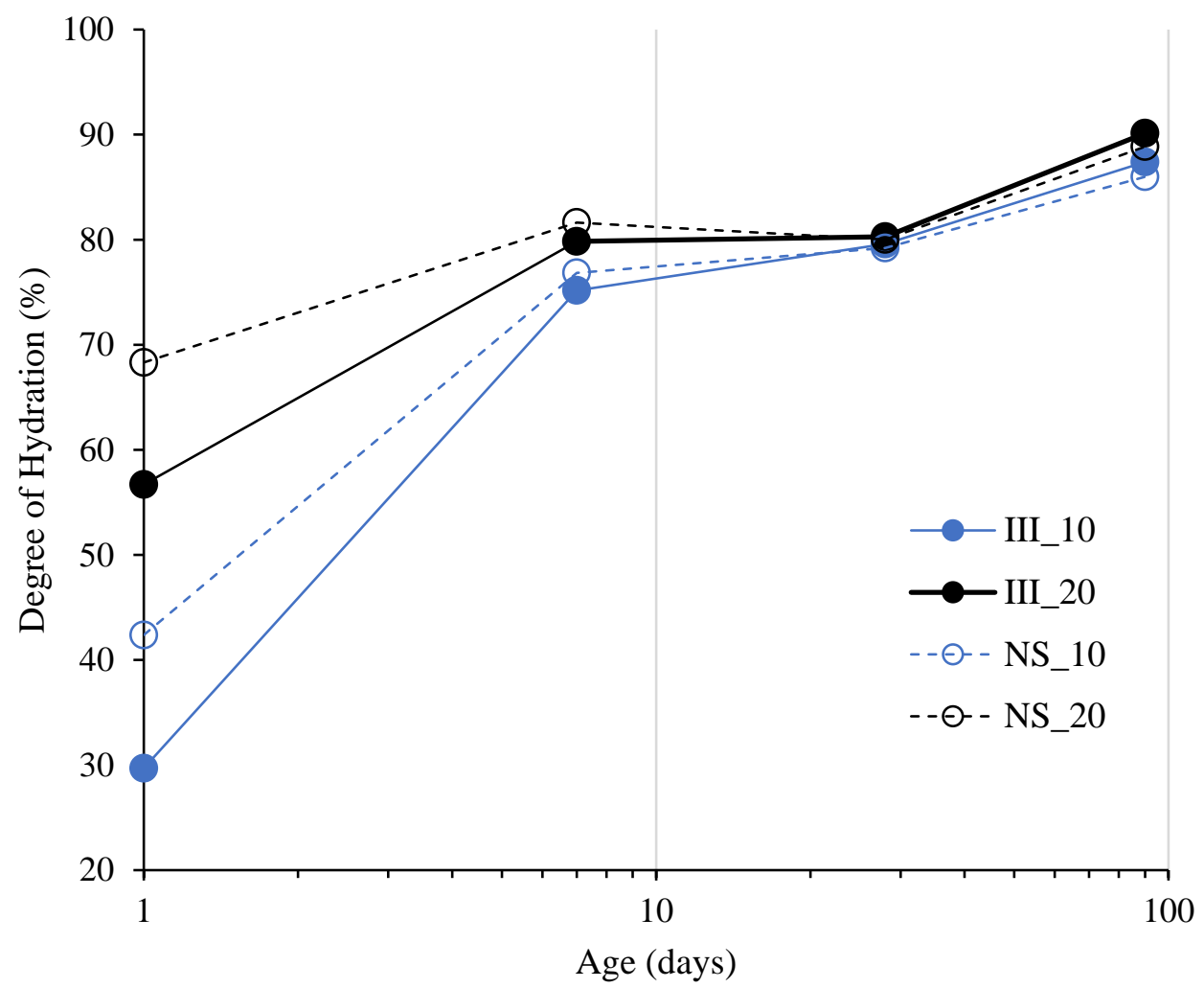

Figure 4. Degree of hydration of clinker in the studied mixes.

The degree of clinker hydration was significantly controlled by the degree of alite $\left(\mathrm{C}_{3} \mathrm{~S}\right)$ hydration of (Table 4). This was expected, due to the high quantities of alite in the clinker, which reacted almost completely. At early ages, the degree of alite hydration increased with the increase in temperature and addition of $\mathrm{Na}_{2} \mathrm{SO}_{4}$. However, not much increase as a response to these factors was recorded after 7 days. The temperature and $\mathrm{Na}_{2} \mathrm{SO}_{4}$ did not seem to influence the degree of alite hydration at 90 days.

Most of the $\mathrm{C}_{3} \mathrm{~A}$ reaction happened from $1 \mathrm{~d}$ to $7 \mathrm{~d}$. Slightly lower degrees of hydration for $C_{3} A$ and $C_{4} A F$ at 90 days were observed in NS systems. $C_{3} A$ is found not to be fully hydrated even after 90 days in NS_10. Some XRD signal reflections for $\mathrm{C}_{3} \mathrm{~A}$ were also observed in NS_20. Even though the difference in the absolute values of the $\mathrm{C}_{3} \mathrm{~A}$ was very small, this phenomenon correlates well with the literature in the presence of $\mathrm{Na}_{2} \mathrm{SO}_{4}[27,50,51]$.

The degree of $\mathrm{C}_{2} \mathrm{~S}$ reaction seems to be negligible or within the error range of the experiment for all the studied samples until 28 days of hydration. However, there was a considerable increase in $\mathrm{DoH}$ of $\mathrm{C}_{2} \mathrm{~S}$ by 90 days. The other slow reacting phase, $\mathrm{C}_{4} \mathrm{AF}$, was found to be more reactive than $C_{2} S$. For both $C_{4} A F$ and $C_{2} S$, the differences between the degree of hydration were within the experimental error. Nevertheless, the increase in $\mathrm{DoH}_{\text {clinker }}$ after 28 days is attributed to the hydration of $\mathrm{C}_{2} \mathrm{~S}$ and $\mathrm{C}_{4} \mathrm{AF}$.

Figure 5 shows the degree of hydration of slag $\left(\mathrm{DoH}_{\text {slag }}\right)$ at 1, 7, 28 and 90 days

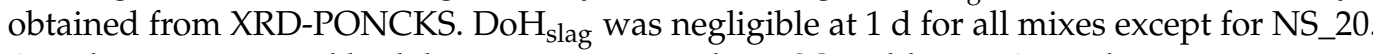
At 7 days, it increased both by temperature and $\mathrm{Na}_{2} \mathrm{SO}_{4}$ addition. At 28 days, $\mathrm{DoH}_{\text {slag }}$ was almost the same for all mixes, except III_10 which was slightly lower than that of others. A striking finding was that $\mathrm{Na}_{2} \mathrm{SO}_{4}$ addition enhanced $\mathrm{DoH}_{\text {slag }}$ at $10{ }^{\circ} \mathrm{C}$ up to 90 days, when the value was $13 \%$ higher than its reference counterpart (III_10). At $20^{\circ} \mathrm{C}$, its impact was mostly seen within the early ages up to 7 days. 


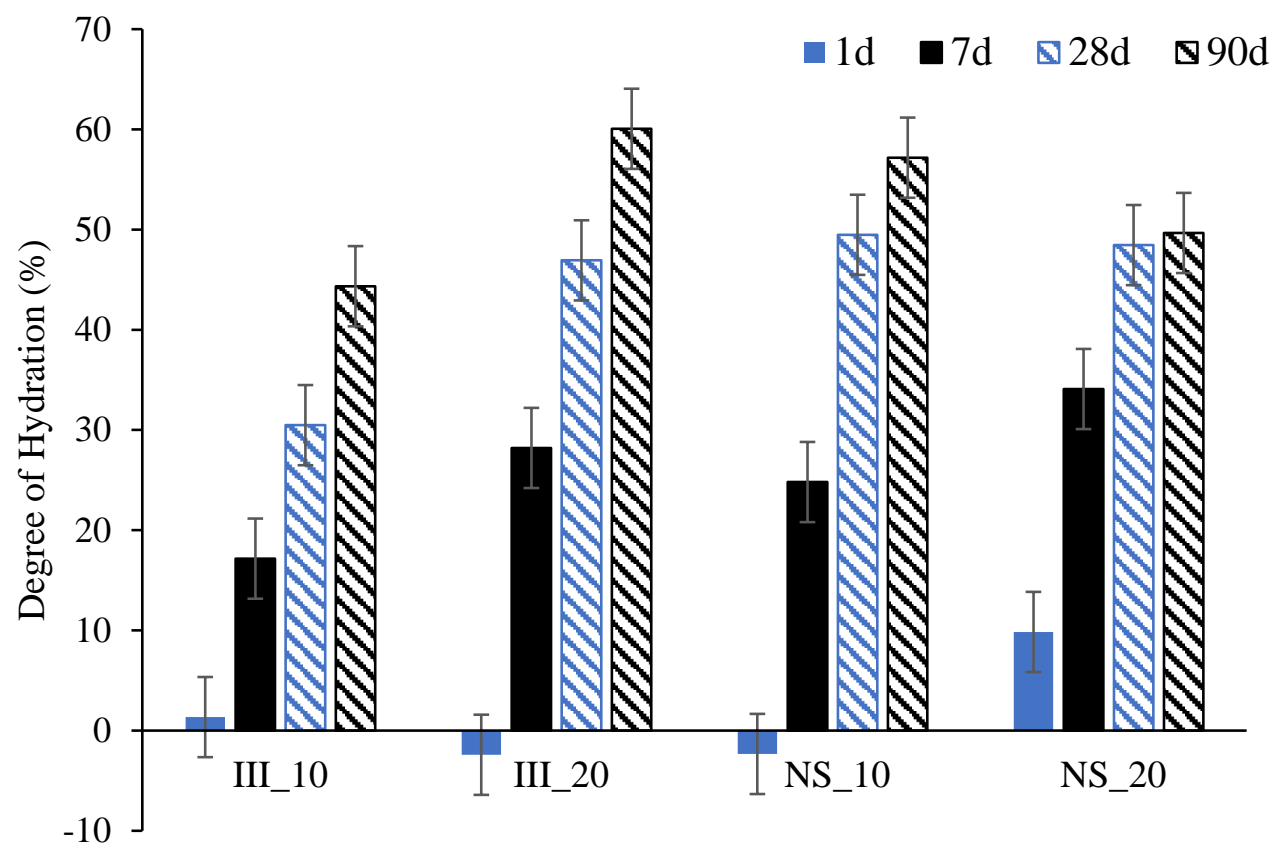

Figure 5. Degree of hydration of slag from XRD-PONCKS method.

\subsection{Phase Assemblage}

The plot of differential thermogravimetric analysis from TGA is shown in Figure 6 for samples after 90 days of hydration. The main mass loss was around $70-150{ }^{\circ} \mathrm{C}$ indicating the decomposition of C-(A)-S-H and ettringite. The mass loss during this peak was significantly higher for NS samples indicating higher ettringite and/or C-(A)-S-H content. A small mass loss at around $350{ }^{\circ} \mathrm{C}$ indicated the decomposition of hydrotalcite $\left(\mathrm{Mg}_{6} \mathrm{Al}_{2} \mathrm{O}_{9} \mathrm{CO}_{3} .12 \mathrm{H}_{2} \mathrm{O}\right)$ [52]. Mass loss associated with portlandite was also clearly visible at around $420-460{ }^{\circ} \mathrm{C}$ and was plotted in Figure 7 . The amount of portlandite content was consistently low at around $2 \mathrm{wt} \%-4 \mathrm{wt} \%$, and remained almost consistent after 1 day of hydration. The low portlandite content was expected due to low clinker content and high amounts of blast furnace slag. NS samples had lower portlandite contents, particularly at $10{ }^{\circ} \mathrm{C}$ and 90 days, when compared to samples without $\mathrm{Na}_{2} \mathrm{SO}_{4}$. This supports higher $\mathrm{DoH}_{\text {slag }}$ in NS_10 compared to III_10 and implies slag-portlandite reaction forming C-(A)$\mathrm{S}-\mathrm{H}$. Further, the difference would be also partially associated with the reaction of $\mathrm{Na}_{2} \mathrm{SO}_{4}$ with portlandite to form gypsum and $\mathrm{NaOH}$.

Figure 8 qualitatively compares the XRD patterns of the samples at 90 days of hydration on freshly cut discs without hydration stoppage procedure. The clinker phases were almost fully reacted in all samples. The main reflections were associated to ettringite and C-(A)-S-H. Higher signals from ettringite reflections are clearly visible in the NS sample. A minor peak associated with hydrotalcite and portlandite peaks are also visible. No crystalline peaks associated with sodium substituted AFm phase (U-phase) [53,54] was found. Also, peaks corresponding to thenardite or mirabilite were not identified in any samples at 90 days, with or without hydration stoppage. Although reflections from thenardite were found from samples with $\mathrm{Na}_{2} \mathrm{SO}_{4}$ after 1 day of hydration, and after hydration stoppage. This is logical as $\mathrm{Na}_{2} \mathrm{SO}_{4}$, which was completely dissolved in pore solution, will precipitate upon drying.

Figure 9 plots the ettringite content quantified from XRD/Rietveld analysis at different ages. Only for the sample cured for 90 days, quantification was done on both freshly sawn disks and powdered samples after hydration stoppage for comparison purposes, while for other ages XRD measurements were only performed after hydration stoppage as a common protocol to suppress the progress of hydration. When the samples with and without hydration stoppage were compared, it was clearly seen that hydration stoppage underestimated the ettringite content quite significantly, which is in agreement with the 
previous studies [55-57]. For all samples, there was a significant increase in the ettringite content from 1 day to 7 days. While comparing samples without $\mathrm{Na}_{2} \mathrm{SO}_{4}$ (III_10 and III_20), the ettringite content seemed to increase for III_10 up to 28 days and decreases at 90 days, while it increases till 7 days and then kept on decreasing at 28 and 90 days for III_20. This indicates the formation of AFm phases after sulphates were fully consumed although this was not evident from XRD, possibly due to lack of long-range order [58]. On the other hand, in the NS samples, the ettringite content kept on increasing until 90 days.

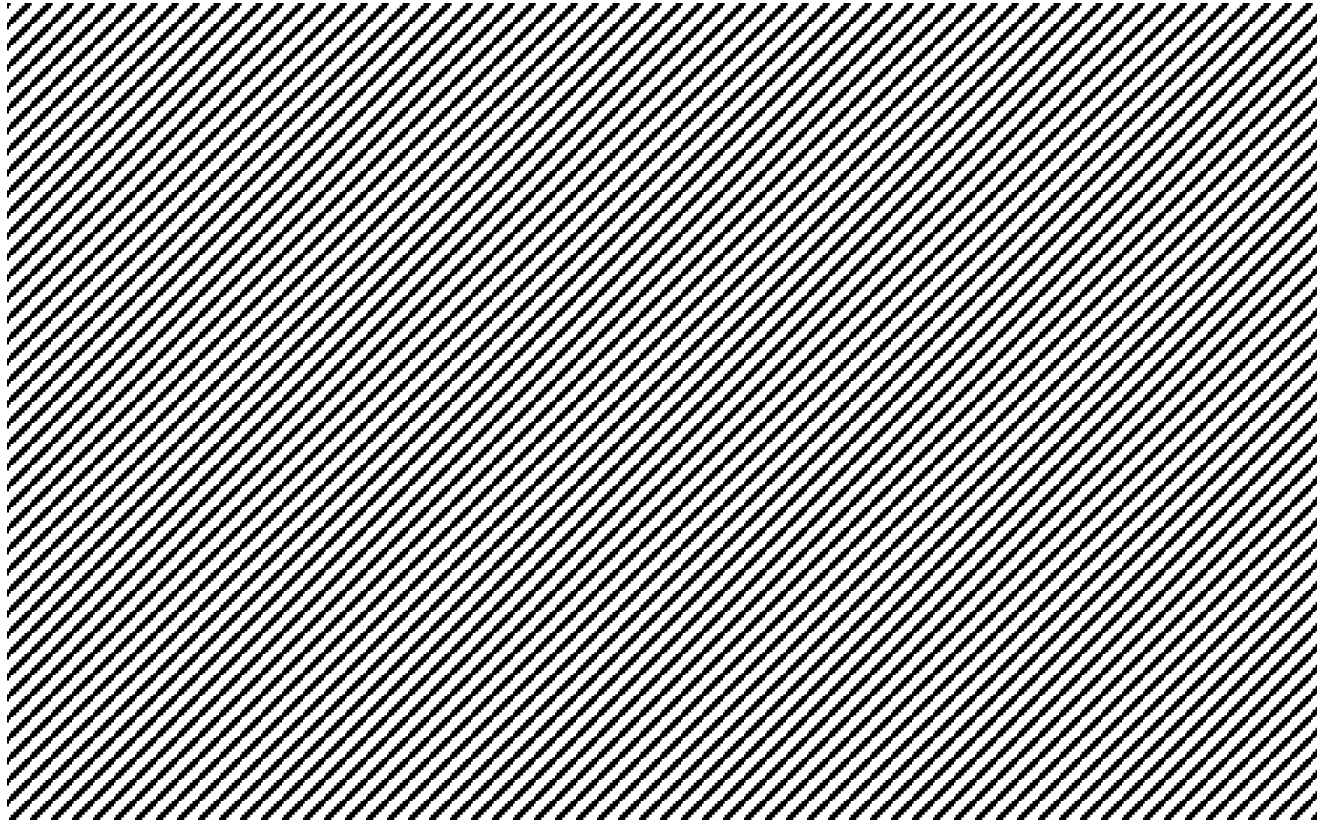

Figure 6. DTG of all mixes after $90 \mathrm{~d}$ hydration. $\mathrm{Ht}-$ hydrotalcite, $\mathrm{CH}-$ portlandite.

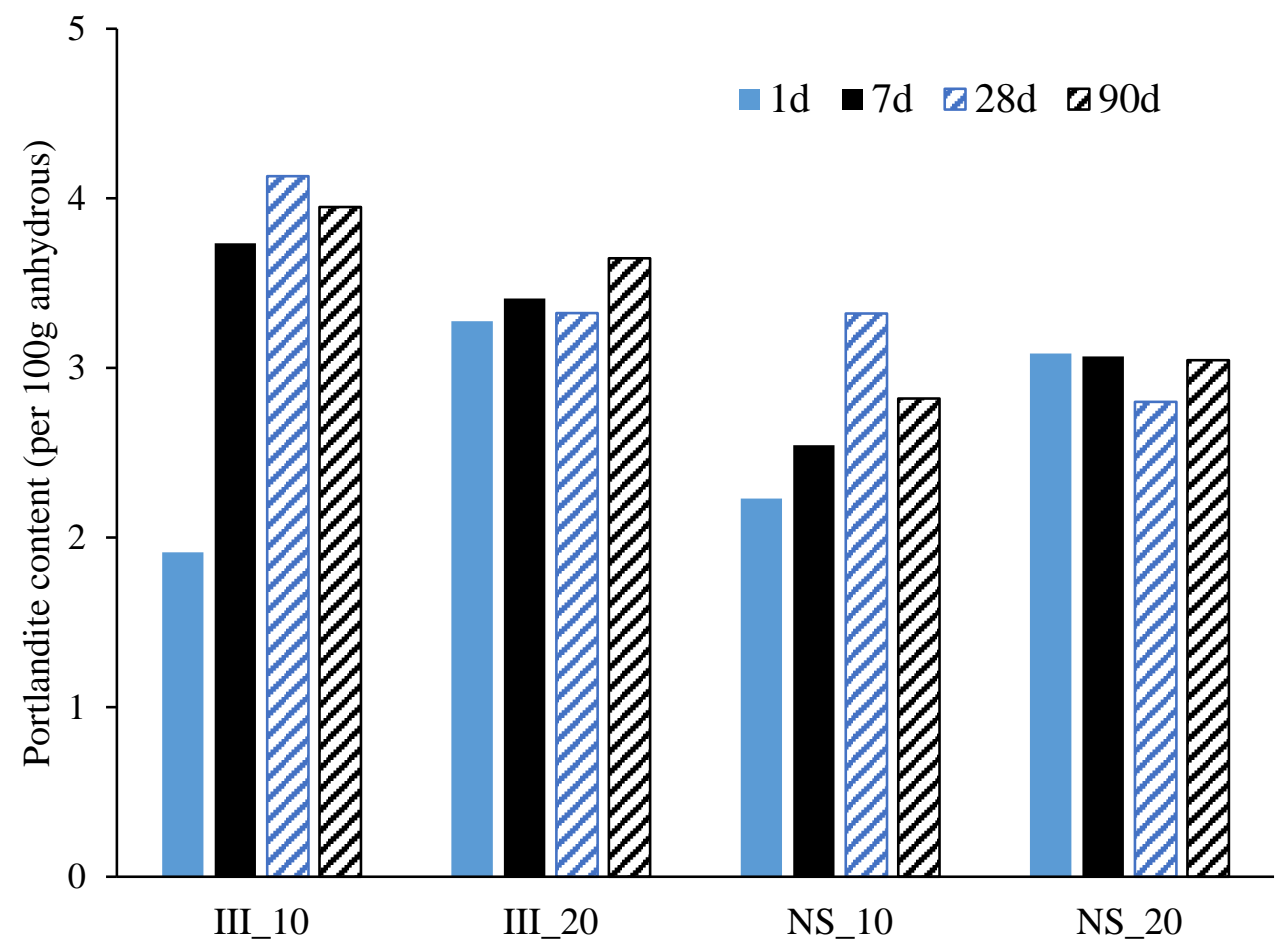

Figure 7. Portlandite content normalized to $\mathrm{g} / 100 \mathrm{~g}$ anhydrous cement, determined from TGAtangent method. 

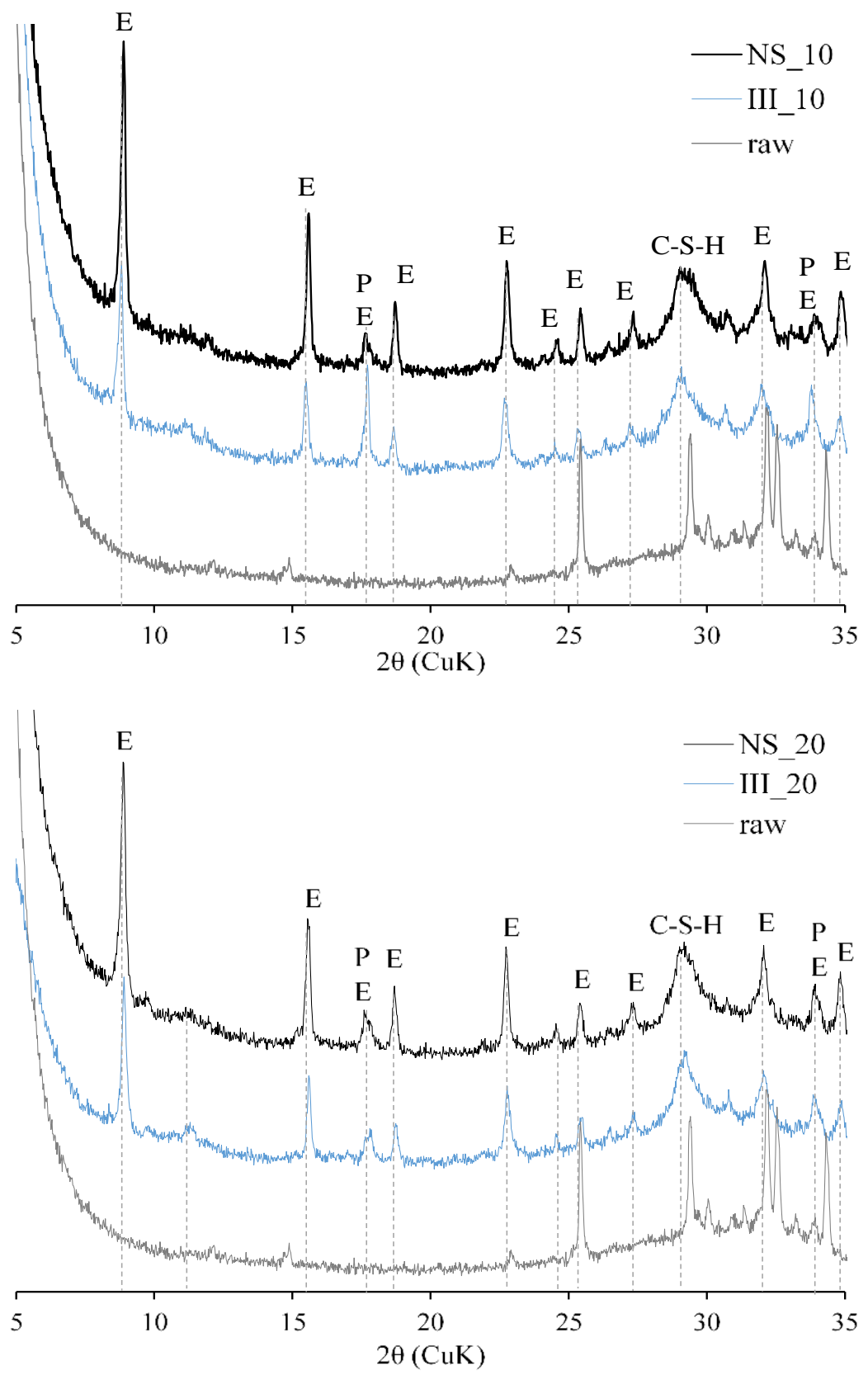

Figure 8. Qualitative XRD of 90 day old fresh samples without hydration stoppage. E-ettringite, $\mathrm{P}$-portlandite, $\mathrm{Ht}$-hydrotalcite.

Figure 10 reports the hydrotalcite content measured from XRD at different ages. After 1 day of hydration, none of the samples showed any signal reflection associated with hydrotalcite. At 7 days, samples without $\mathrm{Na}_{2} \mathrm{SO}_{4}$ had some detectable amounts of hydrotalcite, while NS samples did not have any. By 28 days, hydrotalcite was visible in all samples and became more available by 90 days. The amount of hydrotalcite was higher in the samples without $\mathrm{Na}_{2} \mathrm{SO}_{4}$ at all ages. Furthermore, no systematic differences were observed in the quantities measured in fresh samples and after hydration stoppage and the differences remained within the experimental error $(0.5 \mathrm{wt} \%)$. 


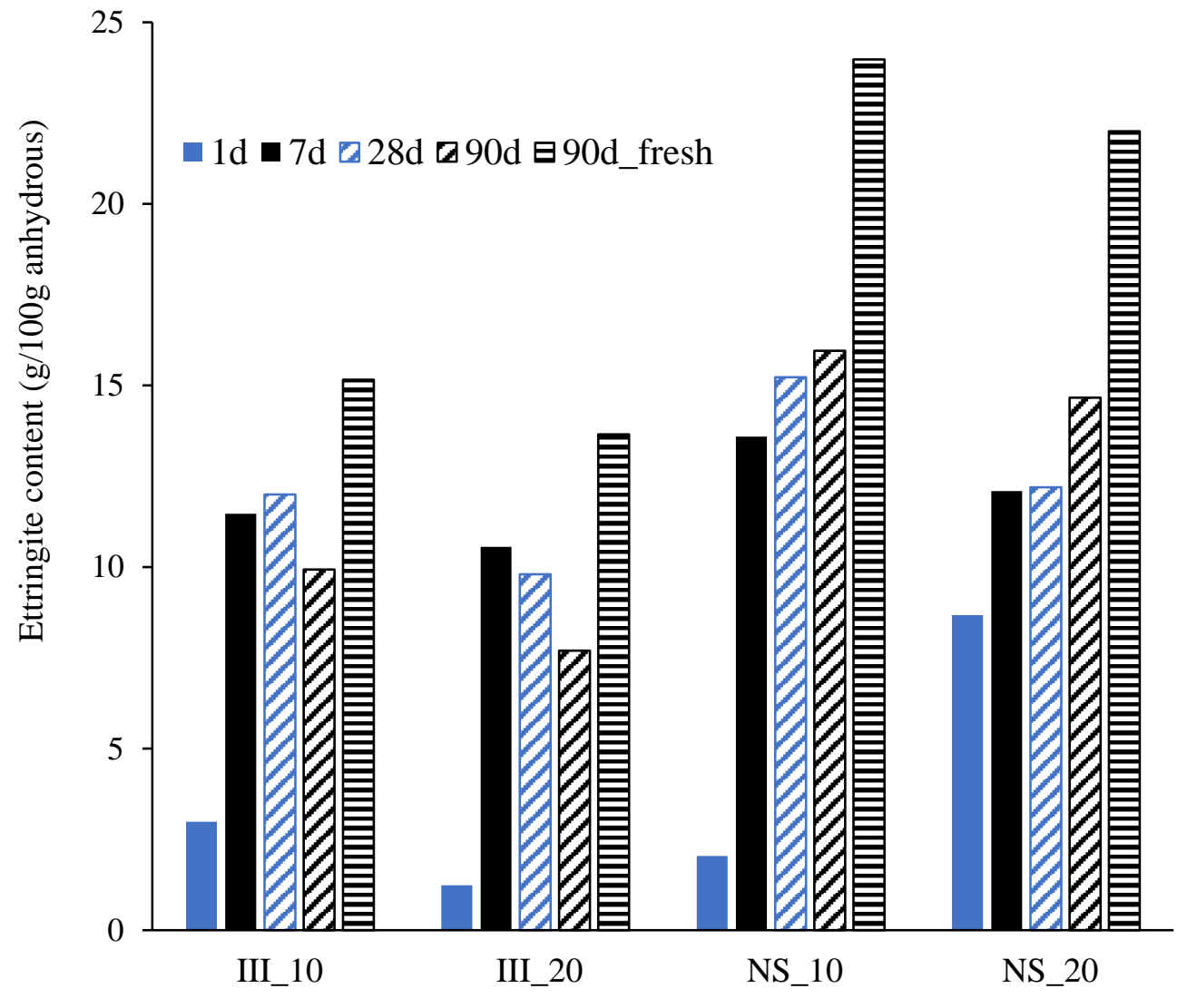

Figure 9. Ettringite content determined from QXRD (g per $100 \mathrm{~g}$ anhydrous cement). $90 \mathrm{~d}$ _fresh indicates the quantitative result on the sample without hydration stoppage.

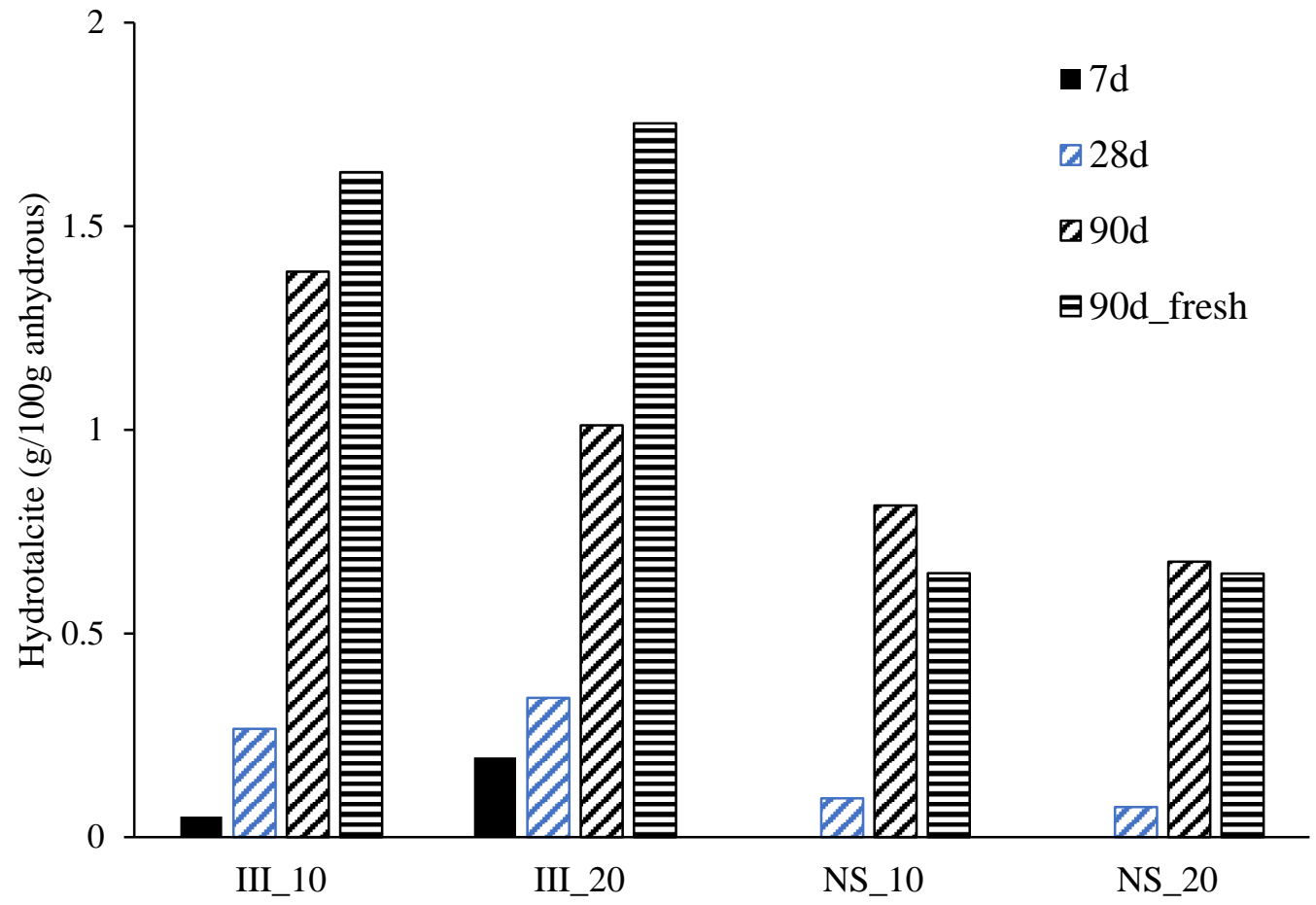

Figure 10. Hydrotalcite content determined from QXRD (g per $100 \mathrm{~g}$ anhydrous) from 7 to 90 days. At 1 day, none of the samples measured had traces of hydrotalcite. The denotation $90 \mathrm{~d}$ _fresh indicates the quantitative result on the sample without hydration stoppage. 
Table 5 reports the elemental ratios of the hydrate phases from SEM-EDX point analysis after 28 days of hydration. The main hydrates, C-(A)-S-H and ettringite were considerably intermixed: hence, the ratios corresponded to the overall hydration products. The $\mathrm{Si} / \mathrm{Ca}$ ratio was higher in NS samples. This corresponded to the $\mathrm{Ca} / \mathrm{Si}$ ratio of 1.85 in the samples without $\mathrm{Na}_{2} \mathrm{SO}_{4}$, and 1.69 in the samples with $\mathrm{Na}_{2} \mathrm{SO}_{4}$. This implies a higher degree of slag reaction and substitution of $\mathrm{Ca}$ with $\mathrm{Na}$. $\mathrm{Na} / \mathrm{Ca}$ ratios were also higher in NS samples as expected. Similarly, S/Ca ratio increases with $\mathrm{Na}_{2} \mathrm{SO}_{4}$ addition due to higher sulphates provided. $\mathrm{Mg} / \mathrm{Si}$ ratios are also higher in NS, indicating a higher degree of slag reaction. Note that hydrotalcite was lower in NS mixes, which could mean that there is a higher incorporation of $\mathrm{Mg}$ in $\mathrm{C}-(\mathrm{A})-\mathrm{S}-\mathrm{H}$. There were no significant differences in $\mathrm{Al} / \mathrm{Ca}$ or $\mathrm{Al} / \mathrm{Si}$ ratios between the samples.

Table 5. Elemental ratios (atomic) for different mixes at 28 days using SEM-EDX analysis.

\begin{tabular}{ccccc}
\hline & III_10 & III_20 & NS_10 & NS_20 \\
\hline $\mathrm{Si} / \mathrm{Ca}$ & $0.54 \pm 0.08$ & $0.54 \pm 0.13$ & $0.59 \pm 0.06$ & $0.59 \pm 0.07$ \\
$\mathrm{Al} / \mathrm{Ca}$ & $0.17 \pm 0.03$ & $0.18 \pm 0.05$ & $0.17 \pm 0.02$ & $0.17 \pm 0.03$ \\
$\mathrm{~S} / \mathrm{Ca}$ & $0.08 \pm 0.03$ & $0.06 \pm 0.03$ & $0.11 \pm 0.03$ & $0.11 \pm 0.02$ \\
$\mathrm{Al} / \mathrm{Si}$ & $0.31 \pm 0.05$ & $0.32 \pm 0.06$ & $0.31 \pm 0.05$ & $0.30 \pm 0.05$ \\
$\mathrm{Mg} / \mathrm{Si}$ & $0.18 \pm 0.07$ & $0.16 \pm 0.09$ & $0.23 \pm 0.09$ & $0.23 \pm 0.12$ \\
$\mathrm{Na} / \mathrm{Ca}$ & $0.01 \pm 0.01$ & $0.02 \pm 0.01$ & $0.12 \pm 0.05$ & $0.08 \pm 0.05$ \\
\hline
\end{tabular}

\subsection{Microstructure}

Figure 11 shows the microstructural slices for all the samples after 28 days of hydration captured on polished samples using SEM-BSE. Most of the unhydrated grains were found to be unreacted slag particles. A small gap between the hydrates and unhydrated slag grains, termed "Hadley grains" $[59,60]$ were visible in all the samples. Both increase in temperature and addition of $\mathrm{Na}_{2} \mathrm{SO}_{4}$ contributed to densification of the microstructure. The addition of $\mathrm{Na}_{2} \mathrm{SO}_{4}$ is known to reduce the bulk density of C-S-H by transforming them into divergent bundles of fibrils $[27,51]$.
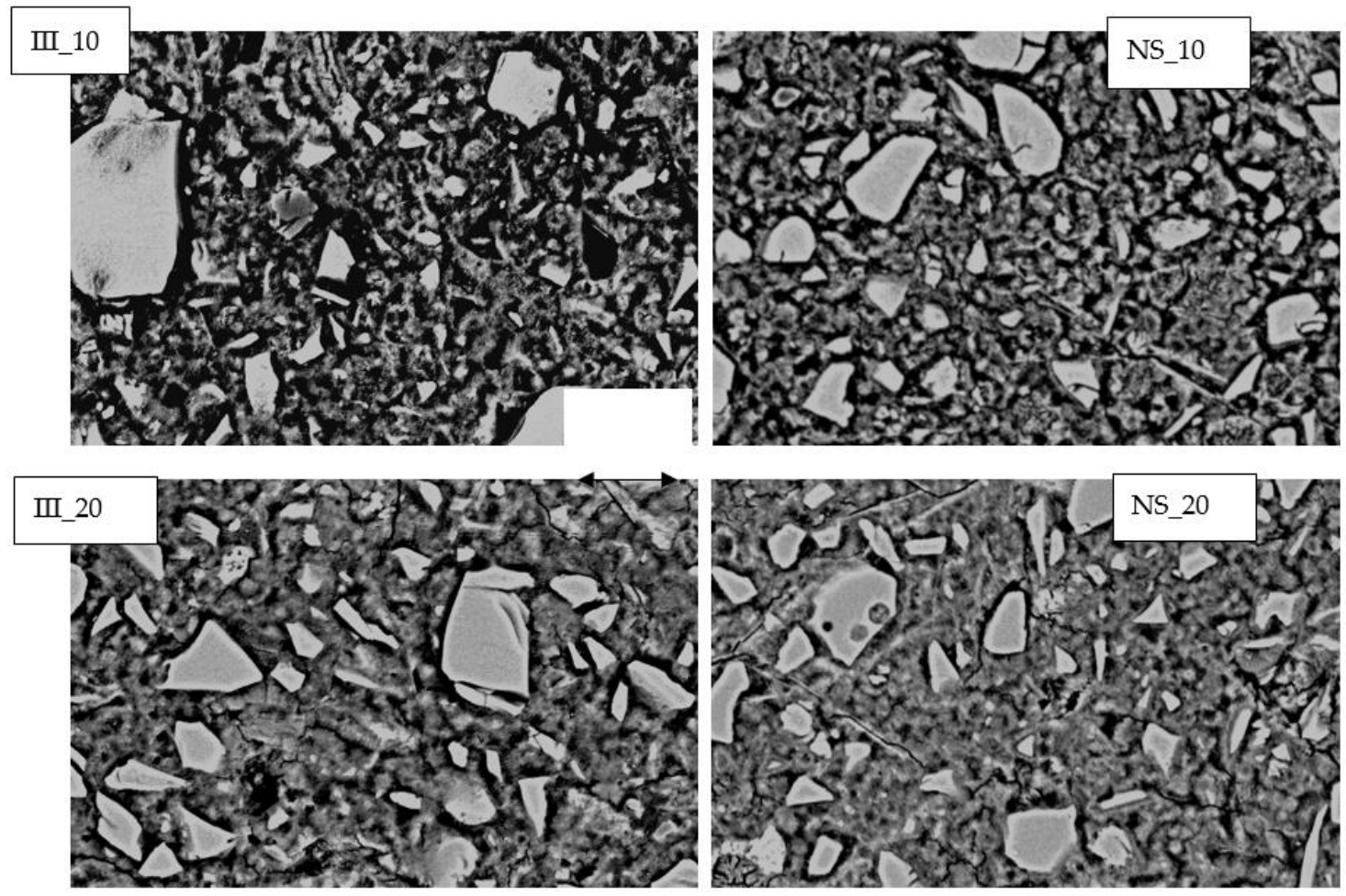

Figure 11. BSE Image of the mixes studied after 28 days of curing. 
Figure 12 shows the pore structure of the pastes measured with MIP after 7 and 28 days of hydration. At 7 days, curing temperature and the addition of $\mathrm{Na}_{2} \mathrm{SO}_{4}$ (NS_20) were favorable to reduce the overall measurable porosity. A considerable pore refinement is also evident from the results. By 28 days of hydration, samples cured at 10 and $20{ }^{\circ} \mathrm{C}$ without $\mathrm{Na}_{2} \mathrm{SO}_{4}$ had very similar microstructure, while a slight reduction in the porosity was seen in NS_20 compared to NS_10. Nevertheless, at the same curing temperature, NS samples had a lower porosity than their reference counterparts.
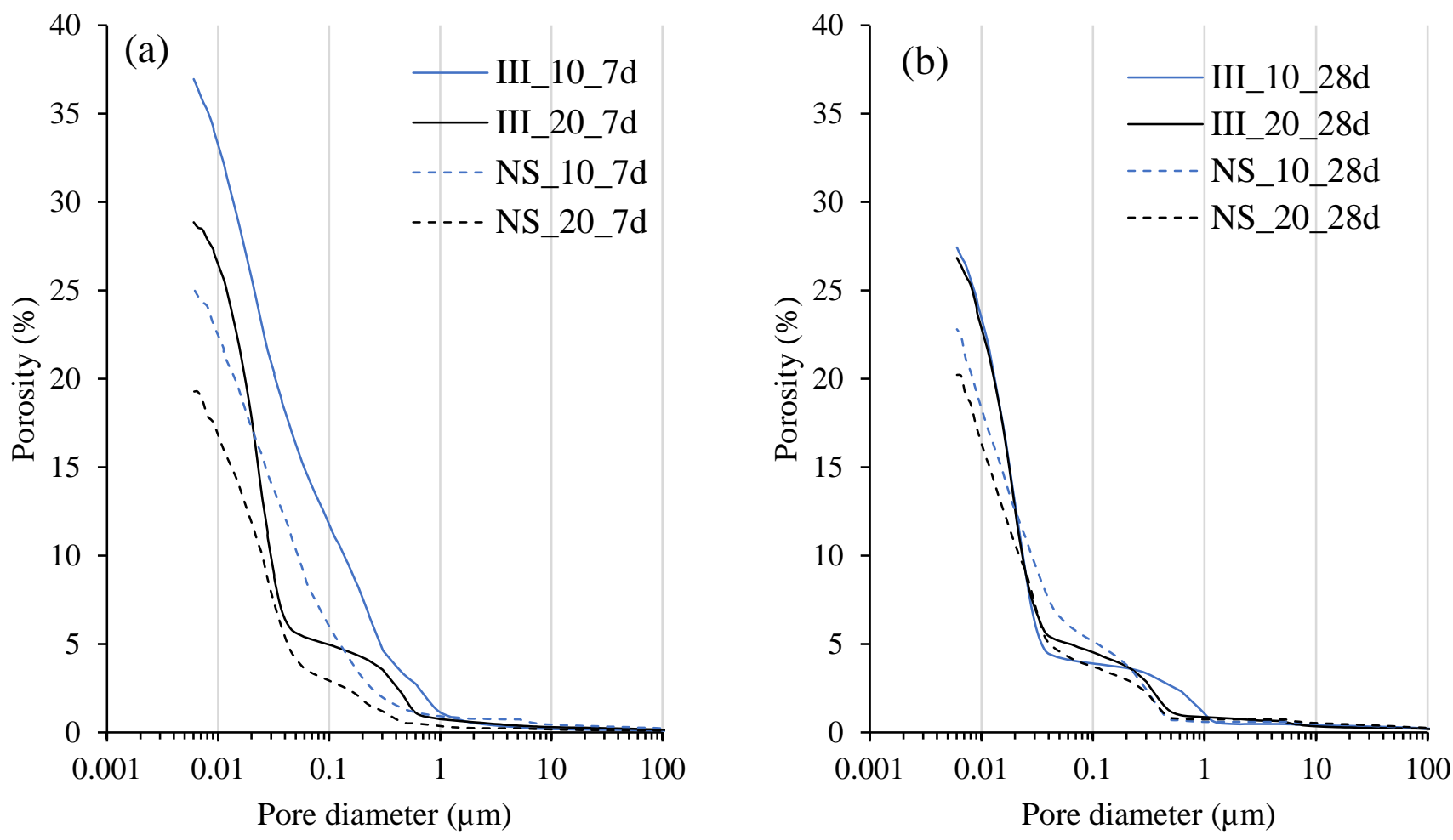

Figure 12. Pore size distribution of the samples determined using MIP after: (a) 7 days and (b) 28 days; of hydration.

\section{Discussion}

\subsection{Second Peak in Isothermal Calorimetry}

Richardson et al. [61] showed that by varying the gypsum content in PC-slag blended systems, the second peak from isothermal calorimetry (third peak if the initial heat release due to the fast dissolution is also to be considered) is associated with the reaction of aluminate. The addition of an alkaline activator such as $\mathrm{Na}_{2} \mathrm{SO}_{4}$ boosts the slag hydration, and it is common for alkali activated slag systems to have a hydration peak around 3-7 days. The area under the second peak (Figure 3a) was calculated using a similar approach that is used to measure the portlandite content from TGA results using tangent analysis (an example is shown in Appendix A, Figure A1). This method provides a rough estimation of the area under the second peak by subtracting the tail of the first peak of hydration. In the NS samples without $\mathrm{Na}_{2} \mathrm{SO}_{4}$ activator, the calculated heat release from the second peak was 13.5 J/g-cement for III_20 and 16.4 J/g-cement for III_10. The area under both peaks, considering the large error associated with the crude approach, appears to be similar. These peaks should be attributed to the main peak of $\mathrm{C}_{3} \mathrm{~A}$ hydration $[59,62,63]$.

In the NS samples activated with $\mathrm{Na}_{2} \mathrm{SO}_{4}$, the second peak appears to be delayed with respect to those ones without $\mathrm{Na}_{2} \mathrm{SO}_{4}$. On the other hand, the area under the peak is significantly higher: 58.9 and $45.0 \mathrm{~J} / \mathrm{g}$-cement for NS_20 and NS_10 respectively. It should be noted that these values are only till $168 \mathrm{~h}$ (7 days) and the second peak of NS_10 was not completed by $168 \mathrm{~h}$. These higher values indicate that this peak cannot be purely associated with $\mathrm{C}_{3} \mathrm{~A}$ hydration as the mass percent of $\mathrm{C}_{3} \mathrm{~A}$ reacted between 1 day and 
7 days with $\mathrm{Na}_{2} \mathrm{SO}_{4}$ was even lower than those without. The theoretical maximum heat release, assuming all the $\mathrm{C}_{3} \mathrm{~A}$ reacted during this period was around $\sim 10-22 \mathrm{~J} / \mathrm{g}$-cement even after considering the quantification error from Rietveld analysis. Thus, in NS samples, the second peak should be attributed to (at least partially) enhanced slag hydration. Figure 5 further shows an increase in the degree of hydration of slag by 7 days in NS samples. It is not clear from the current results if the contribution from the slag was mainly from $\mathrm{Al}_{2} \mathrm{O}_{3}$ phase in the slag.

\subsection{Enthalpy of Slag Hydration}

The degree of hydration of slag can be estimated from isothermal calorimetry, provided that the degree of hydration of clinker phases and the enthalpy of slag hydration are known. Based on the XRD results (Table 4), the heat released from the individual clinker phases was calculated based on the enthalpies of reactions reported in literature: $517 \mathrm{~J} / \mathrm{g}\left(\mathrm{C}_{3} \mathrm{~S}\right)$, $262 \mathrm{~J} / \mathrm{g}\left(\mathrm{C}_{2} \mathrm{~S}\right), 1674 \mathrm{~J} / \mathrm{g}\left(\mathrm{C}_{3} \mathrm{~A}\right.$ to ettringite), $725 \mathrm{~J} / \mathrm{g}\left(\mathrm{C}_{4} \mathrm{AF}\right)$ [40]. When the reported degree of hydration is negative, they are assumed to be zero. Based on these calculations and the results from isothermal calorimeter, after 1 day of hydration the heat release associated to slag hydration was negative $\left(-10\right.$ to $\left.-20 \mathrm{~J} / \mathrm{g}_{\text {-slag }}\right)$. This can be attributed to a combination of negligible slag hydration after 1 day of hydration [10] and the unrecorded heat of hydration in the first $45 \mathrm{~min}$ in calorimeter (due to the time required for paste preparation and stabilization of the temperature within the calorimeter).

On the other hand, after 7 days of hydration, the heat release from slag was estimated to be $86.7,143.8,100.4$ and $212.1 \mathrm{~J} / \mathrm{g}$-slag for III_10, III_20, NS_10 and NS_20 respectively. This further validates the conclusion that with the addition of $\mathrm{Na}_{2} \mathrm{SO}_{4}$ and the increase in curing temperature from $10{ }^{\circ} \mathrm{C}$ to $20{ }^{\circ} \mathrm{C}$, more slag reacted within 7 days. With the help of enthalpy of slag hydration, it would be straightforward to quantitatively determine the degree of hydration of slag. Currently, there is no agreed value for enthalpy of slag hydration, and previous studies estimated this to be 404 to $521 \mathrm{~J} / \mathrm{g}$ [64], $462 \mathrm{~J} / \mathrm{g}$ [65], $530 \mathrm{~J} / \mathrm{g}$ [66]. Such a large variation is expected due to variations in the slag chemistry, complex multiple reactions involved and accuracy limits for quantitative measurements.

From the current study, based on the degree of hydration of slag determined from $\mathrm{XRD}$ and heat release measured from calorimeter, the enthalpy of associated heat release was calculated to be $498,510,587$ and $625 \mathrm{~J} / \mathrm{g}$-slag for III_10, III_20, NS_10 and NS_20 respectively. The error was estimated to be $\sim \pm 60 \mathrm{~J} / \mathrm{g}$-slag. The enthalpy of slag hydration appeared to be higher in the presence of $\mathrm{Na}_{2} \mathrm{SO}_{4}$. Although this was attributed to the enhanced production of ettringite, a further systematic study with more datapoints is required to validate such claims in the next step of research.

\subsection{Strength Development}

While there is a clear improvement in mortar strength in PC-fly ash- $\mathrm{Na}_{2} \mathrm{SO}_{4}$ systems as reported in $[39,67]$, this is arguable for $\mathrm{PC}$-slag- $\mathrm{Na}_{2} \mathrm{SO}_{4}$ systems studied here. Strength improvement in early-ages (until 7 days) with the addition of $\mathrm{Na}_{2} \mathrm{SO}_{4}$ was consistent in the literature, but there were some disagreements in the later-age strength. Zhao et al. [35] reported that the compressive strength is higher with $\mathrm{Na}_{2} \mathrm{SO}_{4}$ activation of 5\% in 50:50 PC-slag blends. The effect of $\mathrm{Na}_{2} \mathrm{SO}_{4}$ was found to be negligible in the later ages with $2 \%$ addition in [31] and 4\% addition in [36]. Fu et al. [33] reported considerable decrease of around $\sim 10 \%$ at 28 days with $1-3 \%$ of $\mathrm{Na}_{2} \mathrm{SO}_{4}$. Mota et al. [30] showed that depending on the type of slag, the later age strength with $\mathrm{Na}_{2} \mathrm{SO}_{4}$ was either comparable or significantly lower with respect to the reference white cement-slag blend. It must be inferred that the effectiveness of $\mathrm{Na}_{2} \mathrm{SO}_{4}$ to activate PC-slag blends depends on the properties of the slag used or PC minerology or both, particularly at later ages. Those factors that affect the later age strength development is currently unknown and needs to be studied further.

Looking back at the results of compressive strength tests (Figure 2), although it can be generalized that the addition of $\mathrm{Na}_{2} \mathrm{SO}_{4}$ and an increase in curing temperature contribute to strength improvement, the reasons for this trend are different at different ages. After 
1 day of hydration, strength was influenced primarily by the alite hydration, as the degree of reaction from other clinker phases and slag was negligible. By 7 days, alite was almost fully reacted for all the systems, and the main difference here was the degree of hydration of slag. By 28 and 90 days, the degree of hydration of clinker was similar for all the systems. Degree of slag reaction was lower for III_10, while other systems had very similar degree of hydration. The main factor, which contributed to the later age strength (28 and 90 days), was found to be the ettringite content. The higher sulphate content originated from the additional $\mathrm{Na}_{2} \mathrm{SO}_{4}$ in $\mathrm{NS}$ systems produced more ettringite. The low density of this hydrate ensured that it filled the microstructure and reduced the porosity of the NS systems.

\section{Conclusions}

The present study investigated the effect of $\mathrm{Na}_{2} \mathrm{SO}_{4}$ on the strength development, hydration and microstructure development of a commercial CEM III/B 42.5 cement cured at 10 and $20^{\circ} \mathrm{C}$. The main conclusions from the study are:

- Compressive strength is enhanced with the addition of $\mathrm{Na}_{2} \mathrm{SO}_{4}$ at all studied ages (1, 7,28 and 90 days) and curing temperatures.

- There is a significant improvement in the degree of hydration of alite after 1 day of hydration with $\mathrm{Na}_{2} \mathrm{SO}_{4}$, but the overall degree of reaction of clinker is very similar at later ages.

- Addition of $\mathrm{Na}_{2} \mathrm{SO}_{4}$ boosts the degree of hydration of slag at early ages (up to 7 days) at both 10 and $20{ }^{\circ} \mathrm{C}$, but in the later ages, higher degree of hydration with $\mathrm{Na}_{2} \mathrm{SO}_{4}$ was only found for the mixture cured at $10^{\circ} \mathrm{C}$.

- Without the addition of $\mathrm{Na}_{2} \mathrm{SO}_{4}$, a clear peak for $\mathrm{C}_{3} \mathrm{~A}$ hydration is visible, but with its addition, although a peak for $\mathrm{C}_{3} \mathrm{~A}$ is not present, there is a clear hydration peak of slag.

- The enthalpy of slag hydration was found to be $498-510 \mathrm{~J} / \mathrm{g}$-slag and $587-625 \mathrm{~J} / \mathrm{g}_{\text {-slag }}$ with and without $\mathrm{Na}_{2} \mathrm{SO}_{4}$ addition respectively. The higher enthalpy with $\mathrm{Na}_{2} \mathrm{SO}_{4}$ should be due to the higher enthalpy of formation of ettringite.

- Ettringite and C-S-H are the major hydrate phases in these systems with and without $\mathrm{Na}_{2} \mathrm{SO}_{4}$, while a significant increase in the amount of ettringite was found for the $\mathrm{Na}_{2} \mathrm{SO}_{4}$ systems.

- Microstructure is densified and the overall porosity decreases with the addition of $\mathrm{Na}_{2} \mathrm{SO}_{4}$

- The improvement of strength with the addition of $\mathrm{Na}_{2} \mathrm{SO}_{4}$ is attributed to the increased reaction of cement phases and slag at early ages, while at later ages, it is due to the higher ettringite content.

Further studies are required to screen the suitable slag/cement $/ \mathrm{Na}_{2} \mathrm{SO}_{4}$ compositions to achieve strength improvement at later ages, and the durability of such systems needs to be further investigated. The high ettringite content in NS mixes points out that such mix compositions would not be suitable for curing at very high temperatures due to the risk of delayed ettringite formation. It is not yet very clear how these compositions will perform against external sulphate attack.

Author Contributions: S.J.: Conceptualization, methodology, software, validation, formal analysis, investigation, resources, data curation, visualization, writing-original draft preparation; Ö.C.: writing - review and editing, supervision. All authors have read and agreed to the published version of the manuscript.

Funding: This research received no external funding.

Data Availability Statement: Not Applicable.

Conflicts of Interest: The authors declare no conflict of interest. 


\section{Appendix A}

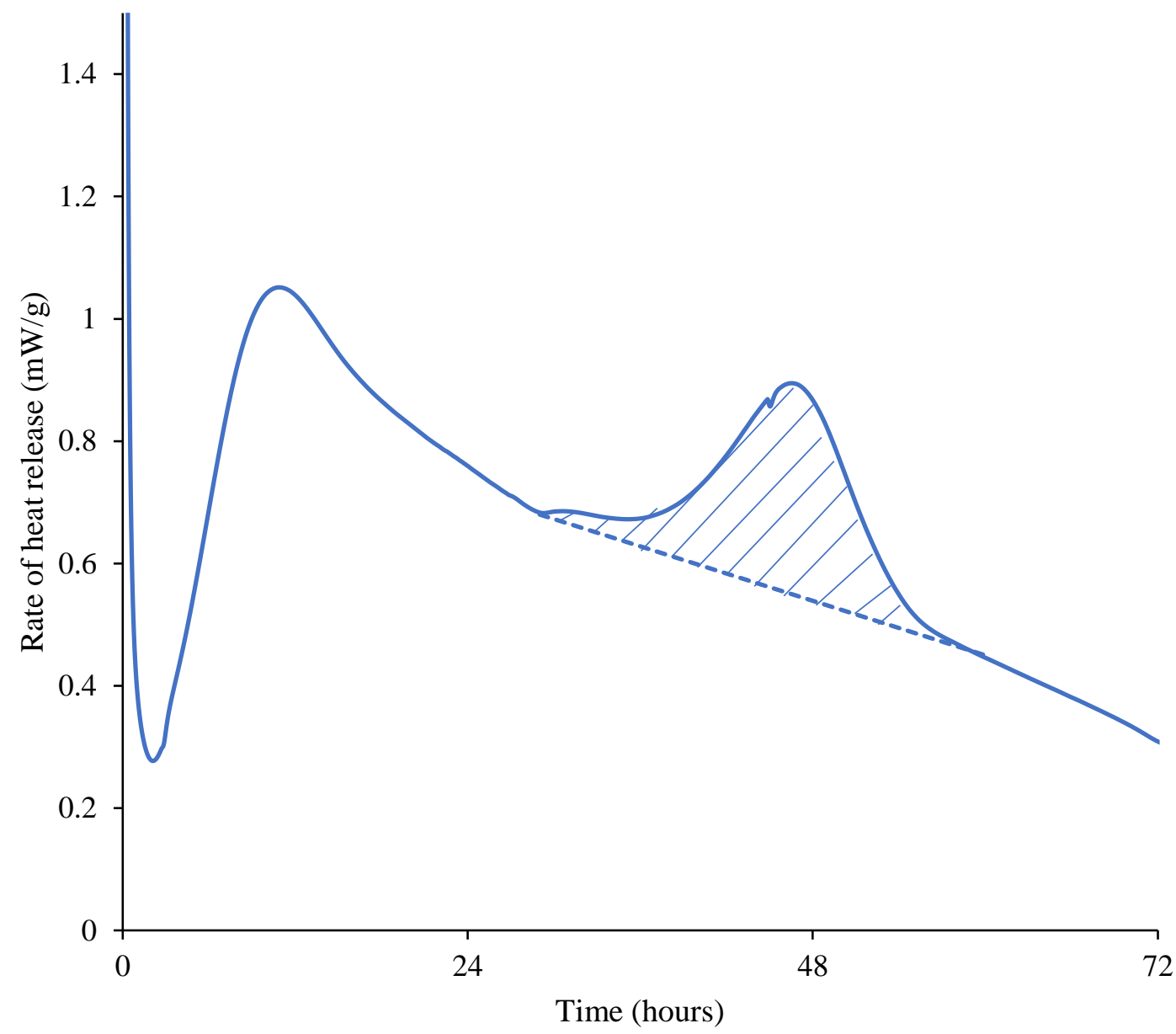

Figure A1. Method adopted to quantify the second hydration peak. The cumulative heat released from the second peak is calculated from the area of the shaded portion.

\section{References}

1. Lang, E. Blast Furnace Cements. In Structure and Performance of Cements; Bensted, J., Barnes, P., Eds.; Spon Press: London, UK, 2002; pp. 310-325.

2. Regourd, M. Cements made from blast furnace slag. In Lea's Chemistry of Cement and Concrete; Butterworth-Heinemann: Oxford, UK, 2001; pp. 637-678.

3. Snellings, R.; Mertens, G.; Elsen, J. Supplementary cementitious materials. Rev. Mineral. Geochem. 2012, 74, 211-278. [CrossRef]

4. Lothenbach, B.; Scrivener, K.; Hooton, R.D. Supplementary cementitious materials. Cem. Concr. Res. 2011, 41, $1244-1256$. [CrossRef]

5. Juenger, M.C.G.; Siddique, R. Recent advances in understanding the role of supplementary cementitious materials in concrete. Cem. Concr. Res. 2015, 78, 71-80. [CrossRef]

6. Skibsted, J.; Snellings, R. Reactivity of supplementary cementitious materials (SCMs) in cement blends. Cem. Concr. Res. 2019, 124, 105799. [CrossRef]

7. Giergiczny, Z. Fly ash and slag. Cem. Concr. Res. 2019, 124, 105826. [CrossRef]

8. Snellings, R. Assessing, Understanding and Unlocking Supplementary Cementitious Materials. RILEM Technol. Lett. 2016, 1, 50. [CrossRef]

9. CEMBUREAU. 2019 Activity Report, Brussels. 2019. Available online: https://cembureau.eu/media/clkdda45/activity-report2019.pdf (accessed on 23 January 2022).

10. Berodier, E.; Scrivener, K. Understanding the filler effect on the nucleation and growth of C-S-H. J. Am. Ceram. Soc. 2014, 97, 3764-3773. [CrossRef]

11. Gutteridge, W.A.; Dalziel, J.A. Filler cement: The effect of the secondary component on the hydration of Portland cement. Cem. Concr. Res. 1990, 20, 778-782. [CrossRef]

12. Cyr, M.; Lawrence, P.; Ringot, E. Mineral admixtures in mortars: Quantification of the physical effects of inert materials on short-term hydration. Cem. Concr. Res. 2005, 35, 719-730. [CrossRef] 
13. Joseph, S.; Bishnoi, S.; Van Balen, K.; Cizer, Ö. Modeling the effect of fineness and filler in early-age hydration of tricalcium silicate. J. Am. Ceram. Soc. 2017, 100, 1178-1194. [CrossRef]

14. Osmanovic, Z.; Haračić, N.; Zelić, J. Properties of blastfurnace cements (CEM III/A, B, C) based on Portland cement clinker, blastfurnace slag and cement kiln dusts. Cem. Concr. Compos. 2018, 91, 189-197. [CrossRef]

15. Demirboğa, R.; Türkmen, I.; Karakoç, M.B. Relationship between ultrasonic velocity and compressive strength for high-volume mineral-admixtured concrete. Cem. Concr. Res. 2004, 34, 2329-2336. [CrossRef]

16. Ganesh Babu, K.; Sree Rama Kumar, V. Efficiency of GGBS in concrete. Cem. Concr. Res. 2000, 30, 1031-1036. [CrossRef]

17. Escalante, J.I.; Gómez, L.Y.; Johal, K.K.; Mendoza, G.; Mancha, H.; Méndez, J. Reactivity of blast-furnace slag in Portland cement blends hydrated under different conditions. Cem. Concr. Res. 2001, 31, 1403-1409. [CrossRef]

18. Barnett, S.J.; Soutsos, M.N.; Millard, S.G.; Bungey, J.H. Strength development of mortars containing ground granulated blastfurnace slag: Effect of curing temperature and determination of apparent activation energies. Cem. Concr. Res. 2006, 36, 434-440. [CrossRef]

19. Miura, T.; Iwaki, I. Strength Development of Concrete Incorporating High Levels of Ground Granulated Blast-Furnace Slag at Low Temperatures. ACI Mater. J. 2000, 97, 66-70.

20. Escalante-García, J.I.; Sharp, J.H. The microstructure and mechanical properties of blended cements hydrated at various temperatures. Cem. Concr. Res. 2001, 31, 695-702. [CrossRef]

21. Sun, Z.; Vollpracht, A. Isothermal calorimetry and in-situ XRD study of the $\mathrm{NaOH}$ activated fly ash, metakaolin and slag. Cem. Concr. Res. 2018, 103, 110-122. [CrossRef]

22. Joseph, S.; Uppalapati, S.; Cizer, Ö. Instantaneous activation energy of alkali activated materials. RILEM Technol. Lett. 2018, 3 , 121-123. [CrossRef]

23. Thomas, J.J. The instantaneous apparent activation energy of cement hydration measured using a novel calorimetry-based method. J. Am. Ceram. Soc. 2012, 95, 3291-3296. [CrossRef]

24. Thomas, J.J.; Ghazizadeh, S.; Masoero, E. Kinetic mechanisms and activation energies for hydration of standard and highly reactive forms of $\beta$-dicalcium silicate (C2S). Cem. Concr. Res. 2017, 100, 322-328. [CrossRef]

25. García-Lodeiro, I.; Fernández-Jiménez, A.; Palomo, A. Variation in hybrid cements over time. Alkaline activation of fly ashportland cement blends. Cem. Concr. Res. 2013, 52, 112-122. [CrossRef]

26. Garcia-Lodeiro, I.; Fernandez-Jimenez, A.; Palomo, A. Hydration kinetics in hybrid binders: Early reaction stages. Cem. Concr. Compos. 2013, 39, 82-92. [CrossRef]

27. Mota-Gasso, B.; Scrivener, T.M.K. Impact of Alkali Salts on the Kinetics and Microstructural Development of Cementitious Systems. L'Ingénieur. Ph.D. Thesis, EPFL, Lausanne, Switzerland, 2015. Available online: https://infoscience.epfl.ch/record/214540 (accessed on 23 January 2022).

28. Smaoui, N.; Bérubé, M.A.; Fournier, B.; Bissonnette, B.; Durand, B. Effects of alkali addition on the mechanical properties and durability of concrete. Cem. Concr. Res. 2005, 35, 203-212. [CrossRef]

29. Hubert, N.; Bouroukba, M.; Schuffenecker, L. Aqueous solution of sodium sulfate. Determination of the dissolution enthalpy at 25, 27.5 and $45^{\circ} \mathrm{C}$. Thermochim. Acta 1995, 259, 41-48. [CrossRef]

30. Mota, B.; Matschei, T.; Scrivener, K. Impact of sodium gluconate on white cement-slag systems with $\mathrm{Na}_{2} \mathrm{SO}_{4}$. Cem. Concr. Res. 2019, 122, 59-71. [CrossRef]

31. Wu, X.; Jiang, W.; Roy, D.M. Early activation and properties of slag cement. Cem. Concr. Res. 1990, 20, 961-974. [CrossRef]

32. Fu, X.; Hou, W.; Yang, C.; Li, D.; Wu, X. Studies on Portland cement with large amount of slag. Cem. Concr. Res. 2000, 30, 645-649. [CrossRef]

33. Fu, J.; Jones, A.M.; Bligh, M.W.; Holt, C.; Keyte, L.M.; Moghaddam, F.; Foster, S.J.; Waite, T.D. Mechanisms of enhancement in early hydration by sodium sulfate in a slag-cement blend-Insights from pore solution chemistry. Cem. Concr. Res. 2020, 135, 106110. [CrossRef]

34. Zhang, J.; Sun, G.; Wang, C.; Zhang, Y.; Wang, P.; Yan, N. Activation effects and micro quantitative characterization of high-volume ground granulated blast furnace slag in cement-based composites. Cem. Concr. Compos. 2020, 109, 103556. [CrossRef]

35. Zhao, Y.; Qiu, J.; Xing, J.; Sun, X. Chemical activation of binary slag cement with low carbon footprint. J. Clean. Prod. 2020, 267, 121455. [CrossRef]

36. Singh, N.; Sarita, R.; Singh, N.B. Effect of sodium sulphate on the hydration of granulated blast furnace slag blended portland cement. Indian J. Eng. Mater. Sci. 2001, 8, 110-113.

37. Joseph, S.; Snellings, R.; Cizer, Ö. Activation of Portland cement blended with high volume of fly ash using $\mathrm{Na}_{2} \mathrm{SO}_{4}$. Cem. Concr. Compos. 2019, 104, 103417. [CrossRef]

38. Taylor, H.F.W. Cement Chemistry; Thomas Telford: London, UK, 1997.

39. Lothenbach, B.; Durdzinski, P.; De Weerdt, K. Thermogravimetric analysis. In A Practical Guide to Microstructural Analysis of Cementitious Materials; Scrivener, K.L., Snellings, R., Lothenbach, B., Eds.; CRC Press: Boca Raton, FL, USA, 2016 ; pp. 177-212.

40. Cheary, R.W.; Coelho, A. Fundamental parameters approach to X-ray line-profile fitting. J. Appl. Crystallogr. 1992, 25, $109-121$. [CrossRef]

41. Snellings, R. X-ray powder diffraction applied to cement. In A Practical Guide to Microstructural Analysis of Cementitious Materials; Scrivener, K.L., Snellings, R., Lothenbach, B., Eds.; CRC Press: Boca Raton, FL, USA, 2016; pp. 107-176. 
42. Scarlett, N.V.Y.; Madsen, I.C. Quantification of phases with partial or no known crystal structures. Powder Diffr. 2006, 21, 278-284. [CrossRef]

43. Snellings, R.; Salze, A.; Scrivener, K.L. Use of X-ray diffraction to quantify amorphous supplementary cementitious materials in anhydrous and hydrated blended cements. Cem. Concr. Res. 2014, 64, 89-98. [CrossRef]

44. Jansen, D.; Goetz-Neunhoeffer, F.; Stabler, C.; Neubauer, J. A remastered external standard method applied to the quantification of early OPC hydration. Cem. Concr. Res. 2011, 41, 602-608. [CrossRef]

45. Villagrán-Zaccardi, Y.A.; Vollpracht, A.; Gruyaert, E.; De Belie, N. Recommendation of RILEM TC 238-SCM: Determination of the degree of reaction of siliceous fly ash and slag in hydrated cement paste by the selective dissolution method. Mater. Struct. Constr. 2018, 51, 27. [CrossRef]

46. Snellings, R.; Bazzoni, A.; Scrivener, K. The existence of amorphous phase in Portland cements: Physical factors affecting Rietveld quantitative phase analysis. Cem. Concr. Res. 2014, 59, 139-146. [CrossRef]

47. Blotevogel, S.; Ehrenberg, A.; Steger, L.; Doussang, L.; Kaknics, J.; Patapy, C.; Cyr, M. Ability of the R3 test to evaluate differences in early age reactivity of 16 industrial ground granulated blast furnace slags (GGBS). Cem. Concr. Res. 2020, 130, 105998. [CrossRef]

48. Qian, J.; Shi, C.; Wang, Z. Activation of blended cements containing fly ash. Cem. Concr. Res. 2001, 31, 1121-1127. [CrossRef]

49. Velandia, D.F.; Lynsdale, C.J.; Provis, J.L.; Ramirez, F.; Gomez, A.C. Evaluation of activated high volume fly ash systems using $\mathrm{Na}_{2} \mathrm{SO}_{4}$, lime and quicklime in mortars with high loss on ignition fly ashes. Constr. Build. Mater. 2016, 128, 248-255. [CrossRef]

50. Fu, J.; Bligh, M.W.; Shikhov, I.; Jones, A.M.; Holt, C.; Keyte, L.M.; Moghaddam, F.; Arns, C.H.; Foster, S.J.; Waite, T.D. A microstructural investigation of a $\mathrm{Na}_{2} \mathrm{SO}_{4}$ activated cement-slag blend. Cem. Concr. Res. 2021, 150, 106609. [CrossRef]

51. Joseph, S.; Skibsted, J.; Cizer, Ö. Hydration of polyphase $\mathrm{Ca}_{3} \mathrm{SiO}_{5}-\mathrm{Ca}_{3} \mathrm{Al}_{2} \mathrm{O}_{6}$ in the presence of gypsum and $\mathrm{Na}_{2} \mathrm{SO}_{4}$. J. Am. Ceram. Soc. 2020, 103, 6461-6474. [CrossRef]

52. Mota, B.; Matschei, T.; Scrivener, $\mathrm{K}$. Impact of $\mathrm{NaOH}$ and $\mathrm{Na}_{2} \mathrm{SO}_{4}$ on the kinetics and microstructural development of white cement hydration. Cem. Concr. Res. 2018, 108, 172-185. [CrossRef]

53. Collier, N.C. Transition and decomposition temperatures of cement phases-A collection of thermal analysis data. Ceram. Silik. 2016, 60, 338-343. [CrossRef]

54. Li, G.; Le Bescop, P.; Moranville, M. Expansion mechanism associated with the secondary formation of the U phase in cementbased systems containing high amounts of $\mathrm{Na}_{2} \mathrm{SO}_{4}$. Cem. Concr. Res. 1996, 26, 195-201. [CrossRef]

55. Li, G.; Le Bescop, P.; Moranville, M. The U phase formation in cement-based systems containing high amounts of $\mathrm{Na}_{2} \mathrm{SO}_{4}$. Cem. Concr. Res. 1996, 26, 27-33. [CrossRef]

56. Snellings, R.; Chwast, J.; Cizer, Ö.; De Belie, N.; Dhandapani, Y.; Durdzinski, P.; Elsen, J.; Haufe, J.; Hooton, D.; Patapy, C.; et al. Report of TC 238-SCM: Hydration stoppage methods for phase assemblage studies of blended cements-Results of a round robin test. Mater. Struct. Constr. 2018, 51, 111. [CrossRef]

57. Knapen, E.; Cizer, O.; Van Balen, K.; Van Gemert, D. Effect of free water removal from early-age hydrated cement pastes on thermal analysis. Constr. Build. Mater. 2009, 23, 3431-3438. [CrossRef]

58. Zhang, L.; Glasser, F.P. Critical examination of drying damage to cement pastes. Adv. Cem. Res. 2000, 12, 79-88. [CrossRef]

59. Joseph, S.; Skibsted, J.; Cizer, Ö. A quantitative study of the C3A hydration. Cem. Concr. Res. 2019, 115, 145-159. [CrossRef]

60. Hadley, D. The Nature of the Paste-Aggregate Interface; Purdue University: West Lafayette, IN, USA, 1972.

61. Kjellsen, K.O.; Lagerblad, B. Microstructure of tricalcium silicate and Portland cement systems at middle periods of hydrationdevelopment of Hadley grains. Cem. Concr. Res. 2007, 37, 13-20. [CrossRef]

62. Richardson, I.G.; Wilding, C.R.; Dickson, M.J. The hydration of blastfurnace slag cements. Adv. Cem. Res. 1989, 2, 147-157. [CrossRef]

63. Minard, H.; Garrault, S.; Regnaud, L.; Nonat, A. Mechanisms and parameters controlling the tricalcium aluminate reactivity in the presence of gypsum. Cem. Concr. Res. 2007, 37, 1418-1426. [CrossRef]

64. Quennoz, K.L. Scrivener, Hydration of C 3A-gypsum systems. Cem. Concr. Res. 2012, 42, 1032-1041. [CrossRef]

65. Kocaba, V.; Gallucci, E.; Scrivener, K.L. Methods for determination of degree of reaction of slag in blended cement pastes. Cem. Concr. Res. 2012, 42, 511-525. [CrossRef]

66. Maekawa, K.; Ishida, T.; Kishi, T. Multi-Scale Modelling of Structural Concrete; Taylor \& Francis: London, UK, 2009.

67. Han, F.; He, X.; Zhang, Z.; Liu, J. Hydration heat of slag or fly ash in the composite binder at different temperatures. Thermochim. Acta 2017, 655, 202-210. [CrossRef] 